\title{
The genetics of amyotrophic lateral sclerosis: current insights
}

\author{
This article was published in the following Dove Press journal: \\ Degenerative Neurological and Neuromuscular Disease \\ 13 May 2016 \\ Number of times this article has been viewed
}

\section{Afnan A Alsultan \\ Rachel Waller \\ Paul R Heath \\ Janine Kirby}

Sheffield Institute for Translational Neuroscience (SITraN), Department of Neuroscience, University of Sheffield, Sheffield, UK
Correspondence: Janine Kirby Sheffield Institute for Translational Neuroscience (SITraN), Department of Neuroscience, University of Sheffield, 385a Glossop Road, Sheffield SIO 2HQ, UK

Tel +44 II 42222247

Fax +44 II 42222290

Email j.kirby@sheffield.ac.uk
Abstract: Amyotrophic lateral sclerosis (ALS) is a progressive neurodegenerative disorder that results in loss of the upper and lower motor neurons from motor cortex, brainstem, and spinal cord. While the majority of cases are sporadic, approximately $10 \%$ show familial inheritance. ALS is usually inherited in an autosomal dominant manner, although autosomal recessive and X-linked inheritance do occur. To date, 24 of the genes at 26 loci have been identified; these include loci linked to ALS and to frontotemporal dementia-ALS, where family pedigrees contain individuals with frontotemporal dementia with/without ALS. The most commonly established genetic causes of familial ALS (FALS) to date are the presence of a hexanucleotide repeat expansion in the C9ORF72 gene (39.3\% FALS) and mutation of SOD1, TARDBP, and FUS, with frequencies of $12 \%-23.5 \%, 5 \%$, and $4.1 \%$, respectively. However, with the increasing use of next-generation sequencing of small family pedigrees, this has led to an increasing number of genes being associated with ALS. This review provides a comprehensive review on the genetics of ALS and an update of the pathogenic mechanisms associated with these genes. Commonly implicated pathways have been established, including RNA processing, the protein degradation pathways of autophagy and ubiquitin-proteasome system, as well as protein trafficking and cytoskeletal function. Elucidating the role genetics plays in both FALS and sporadic ALS is essential for understanding the subsequent cellular dysregulation that leads to motor neuron loss, in order to develop future effective therapeutic strategies.

Keywords: protein degradation, protein trafficking, C9ORF72, TDP-43, RNA processing, autophagy

\section{Introduction}

Amyotrophic lateral sclerosis (ALS) is a progressive neurodegenerative disorder with an incidence of two to three per 100,000 and a lifetime risk of one per 400 individuals. ${ }^{1}$ Usually with an adult onset, initial clinical symptoms, such as loss of dexterity in the fingers or a mild limp in limb onset ALS, or slurring of speech in bulbar onset ALS, are caused by loss of the upper motor neurons in the motor cortex and brainstem and lower motor neurons in the spinal cord. Over time, the progressive nature of the disease is associated with further muscle wasting, weight loss, fasciculations, and eventually death due to respiratory failure, 32 months following symptom onset. ${ }^{1}$ During disease progression, cognitive impairment may develop in up to $40 \%$ of patients, and $\sim 5 \%$ will go on to develop frontotemporal dementia (FTD). ${ }^{1}$

While the majority of cases are sporadic ALS (SALS) with no familial history of disease, $\sim 10 \%$ of cases are familial ALS (FALS) and are clinically indistinguishable from SALS cases. Generally, in adult onset ALS, the disease is inherited as an autosomal 
dominant (AD) trait, although rare cases of juvenile ALS are more commonly associated with autosomal recessive (AR) inheritance. However, there are also instances of AR inheritance of AD genes in specific populations ( $S O D 1$ in Scandinavia and FUS in Cape Verde). In addition, there is evidence of reduced penetrance of disease-associated mutations (including p.I114T SOD1 and G4C2 C9ORF72) and oligogenic inheritance, ${ }^{2}$ illustrating that ALS is a highly complex genetic disorder.

The first genetic cause of ALS was identified in 1993 through linkage analysis to the Chr21 marker DS21S223. Subsequent analysis of the nearby gene, $S O D 1$, identified multiple pathogenic mutations in these FALS families. Over the following 16 years, linkage analysis and candidate gene sequencing of ALS families have identified further genes associated with AD or AR ALS and one instance of X-linked inheritance (Table 1). With the advent of next-generation sequencing, whole exome sequencing (WES) has allowed an exponential increase in the identification of disease-associated genes (Figure 1). Following the first use of WES to identify that the $V C P$ gene was associated with the disease, WES has been used on many FALS samples and assisted in identifying seven further genes in the last 3 years.

To date, $>22$ ALS and four ALS + FTD (FTDALS) loci have been established, with the causative genes identified in the majority of cases. This review summarizes the current insights that have been gained from the four most common causes of FALS: SOD1, TARDBP, FUS, and C9ORF72. These genes have highlighted the roles of oxidative stress and RNA processing as contributory pathogenic mechanisms in ALS. In addition, rarer genetic variants have implicated additional biological pathways such as the ubiquitin-proteasome system (UPS), protein trafficking, and impaired cytoskeletal function. We have used the numbering of loci as described in the Online Mendelian Inheritance in Man Phenotypic Series for ALS (PS105400) and FTDALS (PS105550) in this review. ${ }^{3}$

\section{ALSI: $\mathrm{Cu}-\mathrm{Zn}$ superoxide dismutase (SODI)}

Mutation of $\mathrm{Cu}-\mathrm{Zn}$ superoxide dismutase 1 ( $S O D 1)$ was the first described genetic cause for familial FALS. ${ }^{4}$ The majority of SOD1 mutations are AD, with a highly penetrant pattern of inheritance, and are primarily associated with limb onset ALS. An exception to this rule is the D90A mutation, predominantly found in Scandinavian populations, where it is inherited in an AR manner. Frequency of SOD1 mutations varies depending on populations, from $23.5 \%$ in Scandinavia

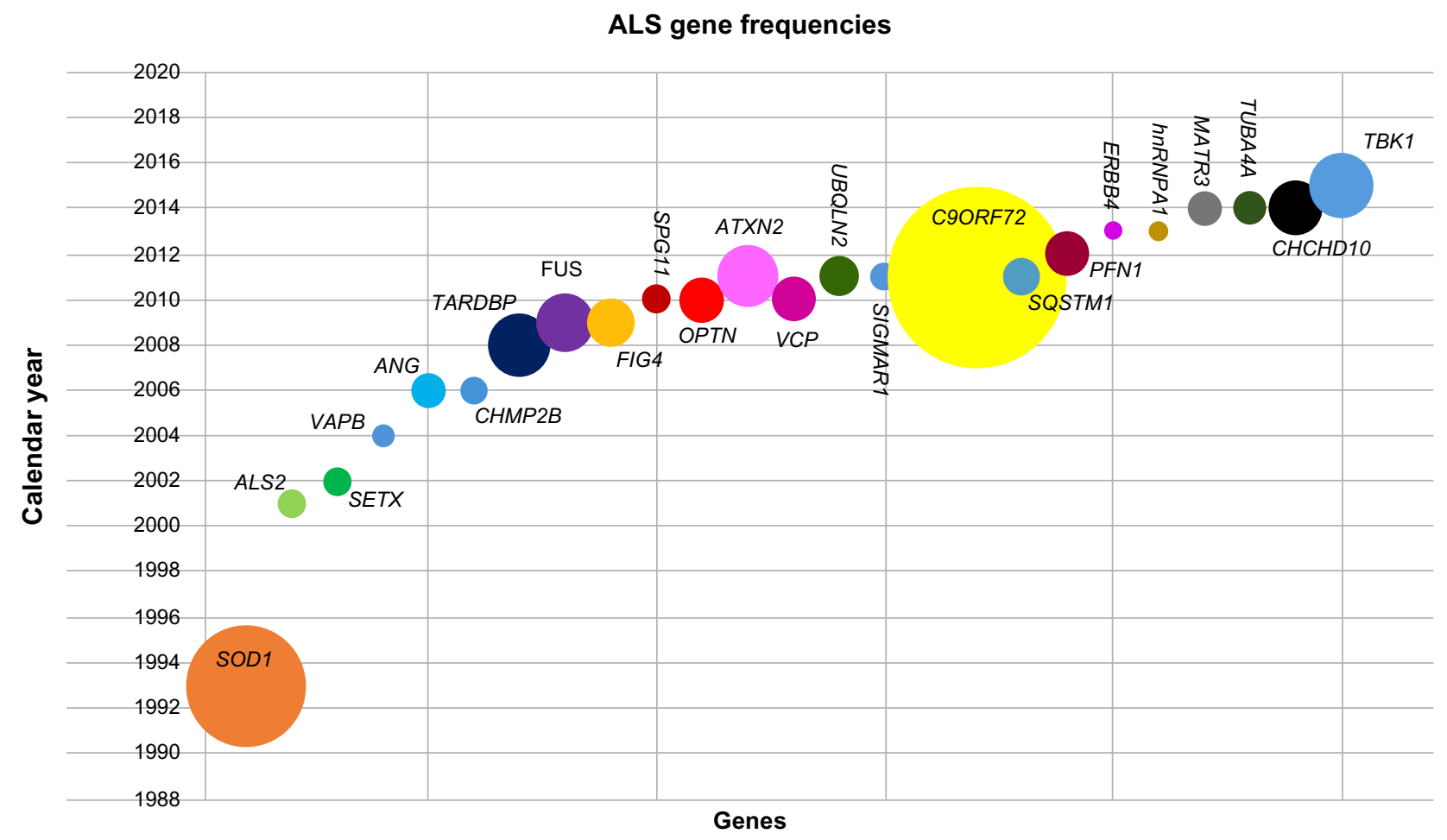

Figure I Gene frequencies in ALS.

Notes: Each gene is plotted against the year it was found; the size of the circles signifies the frequency of mutations in FALS or ALS as cited in the literature. Where gene frequencies were not available, these have been given a circle size equivalent to $1 \%$, for illustrative purposes.

Abbreviations: ALS, amyotrophic lateral sclerosis; FALS, familial ALS. 
Table I Overview of key information available for ALS and FTDALS loci

\begin{tabular}{|c|c|c|c|c|c|c|c|c|c|}
\hline Loci & Method & $\begin{array}{l}\text { Chromosomal } \\
\text { location }\end{array}$ & Gene & $\begin{array}{l}\text { FALS/ALS } \\
\text { frequency } \\
\text { (\%) }\end{array}$ & Year & Onset & Inheritance & $\begin{array}{l}\text { Implicated } \\
\text { pathogenic } \\
\text { mechanisms }\end{array}$ & Reference \\
\hline$\overline{A L S I}$ & Linkage & $21 q 22.11$ & SODI & $\begin{array}{l}\text { Range } \\
\text { I2-23.5 }\end{array}$ & 1993 & Adult & $A D(A R)$ & $\begin{array}{l}\text { Oxidative stress, } \\
\text { UPS, autophagy }\end{array}$ & $\begin{array}{l}\text { Rosen et al, }{ }^{4} \\
* \text { Andersen }{ }^{5}\end{array}$ \\
\hline ALS2 & Linkage & $2 q 33.1$ & ALS2 & Not available & 2001 & Juvenile & $A R$ & Endosomal trafficking & $\begin{array}{l}\text { Hadano et al, }{ }^{95} \\
\text { Yang et al }{ }^{96}\end{array}$ \\
\hline ALS3 & Linkage & $|8 q 2|$ & Unknown & & & Adult & $A D$ & & Hand et al ${ }^{165}$ \\
\hline ALS4 & Linkage & $9 q 34.13$ & SETX & Not available & 2002 & Juvenile & $A D$ & RNA processing & Chen et $\mathrm{al}^{77}$ \\
\hline ALS5 & $\begin{array}{l}\text { Linkage, } \\
\text { candidate gene, } \\
\text { WES }\end{array}$ & $15 q 21.1$ & SPGII & 40 & 2010 & Juvenile & $A R$ & $\begin{array}{l}\text { Intracellular cargo } \\
\text { transport, axonal } \\
\text { growth }\end{array}$ & Orlacchio et al $\left.\right|^{149}$ \\
\hline ALS6 & $\begin{array}{l}\text { Linkage, } \\
\text { candidate gene }\end{array}$ & $16 p \mid 1.2$ & FUS & 4.1 & 2009 & Adult & $A D(A R)$ & $\begin{array}{l}\text { RNA processing, } \\
\text { stress granule function }\end{array}$ & $\begin{array}{l}\text { Vance et al, }{ }^{37} \\
\text { Kwiatkowski et al }{ }^{36}\end{array}$ \\
\hline ALS7 & Linkage & $20 p / 3$ & Unknown & & & Adult & $A D$ & & Sapp et al ${ }^{166}$ \\
\hline ALS8 & Linkage & $20 q \mid 3.32$ & VAPB & $* 0.6$ & 2004 & Adult & $A D$ & $\begin{array}{l}\text { UPR, ER stress, } \\
\text { intracellular } \\
\text { membrane trafficking }\end{array}$ & $\begin{array}{l}\text { Nishimura et al, }{ }^{99} \\
\text { *Milliecamps et al }{ }^{178}\end{array}$ \\
\hline ALS9 & Candidate gene & $|4 q| \mid .2$ & ANG & 1.5 & 2006 & Adult & $A D$ & RNA processing & Greenway et $\mathrm{al}^{73}$ \\
\hline ALSIO & $\begin{array}{l}\text { Linkage, } \\
\text { candidate gene }\end{array}$ & Ip36.22 & TARDBP & $0.5 \%$ ALS, $* 5 \%$ & 2008 & Adult & $A D$ & RNA processing & 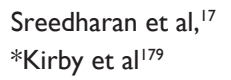 \\
\hline ALSII & Candidate gene & $6 q 21$ & FIG4 & 2.8 & 2009 & Adult & $A D$ & Endosomal trafficking & Chow et al ${ }^{1 / 2}$ \\
\hline ALSI2 & $\begin{array}{l}\text { Family study, } \\
\text { homozygosity } \\
\text { mapping }\end{array}$ & $10 p \mid 3$ & OPTN & 2.6 & 2010 & Adult & $A D(A R)$ & Autophagy & Maruyama et al $\left.\right|^{128}$ \\
\hline ALSI3 & Candidate gene & $12 q 24.12$ & ATXN2 & $4.7 \%$ ALS & 2011 & Adult & $A D$ & RNA processing & Elden et $\mathrm{a}^{80}$ \\
\hline ALSI4 & $\begin{array}{l}\text { Family study, } \\
\text { WES }\end{array}$ & $9 p \mid 3.3$ & $V C P$ & 2.4 & 2010 & Adult & $A D$ & Autophagy & Johnson et al $\left.\right|^{134}$ \\
\hline ALSI5 & Linkage & $X p \mid I .21$ & UBQLN2 & 2.1 & 2011 & Adult & X-LD & UPS, autophagy & Deng et al ${ }^{116}$ \\
\hline ALSI6 & $\begin{array}{l}\text { Family study, } \\
\text { homozygosity } \\
\text { mapping }\end{array}$ & $9 \mathrm{p} / 3.3$ & SIGMARI & Not available & 2011 & Juvenile & $A D, A R$ & $\begin{array}{l}\text { UPR, ER stress, } \\
\text { proteasome function }\end{array}$ & $\begin{array}{l}\text { Luty et al, }{ }^{125} \\
\text { Al-Saif et al }{ }^{126}\end{array}$ \\
\hline ALSI7 & $\begin{array}{l}\text { Linkage, } \\
\text { candidate gene }\end{array}$ & $3 p \mid 1.2$ & $C H M P 2 B$ & $* 1 \%$ ALS & 2006 & Adult & $A D$ & $\begin{array}{l}\text { Endosomal trafficking, } \\
\text { autophagy }\end{array}$ & $\begin{array}{l}\text { Parkinson et al, }{ }^{\prime 10} \\
{ }^{*} \text { Cox et al }{ }^{111}\end{array}$ \\
\hline ALSI8 & $\begin{array}{l}\text { Family study, } \\
\text { WES }\end{array}$ & $|7 p| 3.2$ & PFNI & 2.5 & 2012 & Adult & $A D$ & $\begin{array}{l}\text { Cytoskeleton, } \\
\text { axonal growth }\end{array}$ & Wu et $\mathrm{al}^{151}$ \\
\hline ALSI9 & $\begin{array}{l}\text { Family study, } \\
\text { WGS }\end{array}$ & $2 q 34$ & ERBB4 & 0.5 & 2013 & Adult & $A D$ & Neuronal development & Takahashi et al ${ }^{167}$ \\
\hline ALS20 & $\begin{array}{l}\text { WES, candidate } \\
\text { gene }\end{array}$ & $12 q 13.13$ & hnRNPAI & 0.5 & 2013 & Adult & $A D$ & RNA processing & Kim et $\mathrm{al}^{84}$ \\
\hline ALS2I & $\begin{array}{l}\text { Family study, } \\
\text { WES }\end{array}$ & $5 q 31.2$ & MATR3 & 1.5 & 2014 & Adult & $A D$ & RNA processing & Johnson et $\mathrm{al}^{87}$ \\
\hline ALS22 & $\begin{array}{l}\text { Family study, } \\
\text { WES }\end{array}$ & $2 q 35$ & TUBA4A & $\mathrm{I} .4$ & 2014 & Adult & $A D$ & Cytoskeleton & Smith et al ${ }^{159}$ \\
\hline FTDALSI & $\begin{array}{l}\text { GWAS, linkage, } \\
\text { targeted NGS }\end{array}$ & $9 p 21.2$ & C9ORF72 & $* 39.3$ & 2011 & Adult & $A D$ & $\begin{array}{l}\text { RNA processing, } \\
\text { endosomal trafficking, } \\
\text { autophagy }\end{array}$ & $\begin{array}{l}\text { Renton et al, }{ }^{49} \\
\text { Dejesus-Hernandez } \\
\text { et al, }{ }^{50} \\
* \text { Majounie et } \mathrm{al}^{51}\end{array}$ \\
\hline FTDALS2 & $\begin{array}{l}\text { Family study, } \\
\text { WES }\end{array}$ & $22 q 11.23$ & $\mathrm{CHCHDIO}$ & $* 3.6$ & 2014 & Adult & $A D$ & $\begin{array}{l}\text { Mitochondrial } \\
\text { function }\end{array}$ & $\begin{array}{l}\text { Bannwarth et al, }{ }^{169} \\
\text { *Johnson et a }{ }^{87}\end{array}$ \\
\hline FTDALS3 & Candidate gene & $5 q 35.3$ & SQSTMI & 1.8 & 2011 & Adult & $A D$ & $\begin{array}{l}\text { Protein degradation, } \\
\text { autophagy }\end{array}$ & Fecto et al ${ }^{\mid 21}$ \\
\hline FTDALS4 & $\begin{array}{l}\text { Family study, } \\
\text { WES }\end{array}$ & $12 q \mid 4.2$ & TBKI & 5.2 & 2015 & Adult & $A D$ & $\begin{array}{l}\text { Autophagy, } \\
\text { neuroinflammation }\end{array}$ & $\begin{array}{l}\text { Freischmidt et al, }{ }^{143} \\
\text { Cirulli et al }{ }^{142}\end{array}$ \\
\hline
\end{tabular}

Notes: ALS and FTDALS loci numbering is determined by the phenotypic series information available within Online Mendelian Inheritance in Man, OMIM ${ }^{\circledR}{ }^{3}$ The frequency of mutations within FALS originates from the original paper or from the reference marked with an asterisk (*). In some cases, frequency in ALS, rather than FALS, is provided. Abbreviations: ALS, amyotrophic lateral sclerosis; FTDALS, frontotemporal dementia and ALS; FALS, familial ALS; WES, whole exome sequencing; WGS, whole genome sequencing; UPS, ubiquitin-proteasome system; UPR, unfolded protein response; AD, autosomal dominant; AR, autosomal recessive; X-LD, X-linked, dominant; ER, endoplasmic recticulum; GWAS, genome-wide association study; NGS, next generation sequencing. 
to $12 \%$ in Germany; mutations have also been identified in apparently sporadic cases. ${ }^{5}$ The ALSoD database (http:// alsod.iop.kcl.ac.uk $)^{6}$ reports that there are 183 mutations in SOD1 associated with disease (accessed November 2015), the majority of which are point mutations. Given that SOD1 encodes a 153 amino acid protein, this number is remarkable, with the mutations distributed throughout the gene and impacting upon a variety of domains within the protein. This is in contrast to some of the other ALS-associated mutations, which are more often located within a particular motif of the protein product, particularly as it is unclear whether all the reported SOD1 "mutations" are indeed pathogenic.,

The multiple mutations throughout the protein have also resulted in challenges determining how they are responsible for the disease phenotype. SOD1 is a ubiquitously expressed antioxidant protein, which catalyzes free radical superoxide to hydrogen peroxide and oxygen. As the majority of mutant proteins retain this enzymatic function, the pathogenicity is proposed to act through a toxic gain of function, although the precise nature of this toxicity remains to be determined. Many mutually compatible pathogenic mechanisms have been proposed including oxidative stress, excitotoxicity, protein aggregation, neuroinflammation, apoptosis, mitochondrial dysfunction, axonal transport dysregulation, and endoplasmic reticulum (ER) stress. ${ }^{9}$ Mutant SOD1 proteins (mtSOD1) show variable states of metallation and disulfide bond formation, which leads to the ability of the demetalled and unfolded apoform to enter the intermembrane space of the mitochondrion, thereby causing mitochondrial dysfunction. ${ }^{10}$ In addition, demetallation leads to increased instability and mtSOD1 shows a higher aggregation propensity than wild-type SOD1. More recently, mtSOD1, along with misfolded wild-type SOD1, has been shown to move from cell to cell and initiate a prion-like seeded aggregation of SOD1. ${ }^{11,12}$ While initial work demonstrated the propagation of misfolded protein in cell culture models, spinal homogenates from paralyzed mutant G93A SOD1 mice injected into 6-month-old G85R-SOD1:YFP mice (who do not usually get disease till 20 months) produced a progressive motor neuron disease within 3 months. ${ }^{13}$

Normally, misfolded proteins are removed from the cell via the UPS. However, in SOD1-ALS, and also in SALS, the UPS has been shown to be impaired. ${ }^{14,15}$ In addition, mahogunin ring finger 1, an E3 ubiquitin ligase, which catalyzes monoubiquitination of proteins and marks them for degradation via a UPS-independent mechanism, has been shown to be decreased in the G93A mouse model. Interestingly, however, overexpression of this protein reduced SOD1 toxicity by suppressing the aggregation of SOD1. Thus, therapeutic strategies for ALS include increasing clearance of misfolded SOD1, and the heat-shock protein inducer, arimoclomol, is one such drug currently under investigation. ${ }^{16}$

While initially oxidative stress was thought to be one of the primary mechanisms of mutant SOD1, the continued research on SOD1 pathogenic mechanisms has implicated UPS, protein aggregation, and degradation, as well as other aspects of protein trafficking. These pathways are also implicated by the discovery of additional FALS genes ("Protein trafficking and degradation-related genes" section).

\section{ALS I0: TAR DNA-binding protein (TARDBP)}

The transactive response DNA-binding protein 43 (TDP-43) is encoded by TARDBP gene on chr1p36.22. ${ }^{17}$ TARDBP is responsible for $4 \%-5 \%$ of FALS and nearly $1 \%$ of SALS. ${ }^{18}$ Mutations in TARDBP are inherited in an AD manner and are associated with a classic ALS clinical phenotype. TARDBP encodes several isoforms of which TDP-43 is considered the most prevalent. TDP-43 is a heterogeneous nuclear ribonucleoprotein (hnRNP) with a nuclear localization signal (NLS) and nuclear export signal, which allows shuttling of the protein between the nucleus and cytoplasm. The TDP-43 protein contains three further domains, two RNA recognition motifs (RRM1 and RRM2), involved in RNA and DNA binding, and a glycine-rich domain, which is essential for interactions with other proteins and is the location of the majority of mutations. ${ }^{19,20}$

TDP-43 was initially identified as a transcription repressor that binds to TAR DNA in human immunodeficiency virus-1. ${ }^{27}$ Subsequently, TDP-43 has been shown to play a role in RNA metabolism, including RNA transcription, alternative splicing, pre-microRNA processing, RNA transport, and messenger RNA (mRNA) stability. ${ }^{22}$ TDP-43 has the ability to autoregulate its own gene expression by binding to the $3^{\prime}$ untranslated region ( $3^{\prime} \mathrm{UTR}$ ) of its mRNA, leading to instability and decay. ${ }^{23}$ TDP-43 also binds to UG-rich sequences in multiple mRNA sequences to regulate splicing. ${ }^{24-26}$ In addition, a novel function has recently been described, with TDP-43 able to repress the splicing of nonconserved exons known as cryptic exons. ${ }^{27}$ Removal of TDP-43 allowed these cryptic exons to be incorporated into mRNA sequences, which subsequently disrupted translation and induced nonsense mediated decay. Finally, TDP-43 is also known to be a component of stress granules (SGs), although it is unclear whether this role contributes to neurodegeneration. ${ }^{28}$ 
TDP-43 is a prominent protein in the characteristic ubiquitinated cytoplasmic inclusions found in patients with ALS and FTD. ${ }^{29}$ Approximately $97 \%$ of patients with FALS and SALS are positive for TDP-43 inclusions in the motor cortex and spinal cord, thereby establishing TDP-43 as a major protein signature for disease, not just those carrying TARDBP mutations. ${ }^{17,30}$ The loss of TDP-43 nuclear localization in ALS is well documented, and the resulting splicing deficits in ALS cellular and animal models and in patient samples have been reported. ${ }^{27,31,32} \mathrm{In}$ addition to a loss of nuclear function, a cytoplasmic gain of function may also contribute to neurodegeneration. A mouse model with a mutation in the NLS of human TARDBP, thereby limiting TDP-43 to the cytoplasm, showed increased expression of transcription-related and chromatin assembly genes and histone 3'UTR processing genes. ${ }^{33}$ Importantly, these transcriptional changes were not seen when an antisense oligomer was added to knockdown TDP-43 expression, thereby supporting a cytoplasmic toxic gain of function. Finally, similar to the prion-like propagation of disease described in SOD-ALS, there is also evidence that wild-type TDP-43 oligomers can spread horizontally from cell to cell via microvesicles, including the brain lysates of patients with ALS, as well as vertically along axons. ${ }^{34}$ Thus, reducing the aggregation of these mutant proteins is becoming a more widely applicable therapeutic strategy.

\section{ALS6: fused in sarcoma (FUS)}

The FUS gene on chr16p11.2 was first identified as a fusion oncogene in liposarcoma. FUS belongs to the FET protein family and has been shown to be an hnRNP due to its involvement in the transcription process, transport, trafficking, alternative splicing, and microRNA processing. Similar to TDP-43, it is also present in SGs. Structurally, FUS is composed of 526 amino acids that form an N-terminal domain rich in glutamine-glycine-serine-tyrosine (QGSY), three arginine-glycine-glycine (RGG)-rich domains, an RRM, and a zinc finger motif, as well as nuclear export signal and NLS that enable nucleocytoplasmic shuttling of the protein. ${ }^{35}$

Mutations in the FUS gene were initially identified in an AR Cape Verde family, ${ }^{36}$ although subsequent screening established FUS to be causative also in AD ALS. ${ }^{36,37}$ FUS mutations account for $4 \%$ of FALS and $1 \%$ of SALS, with the majority of mutations located either within exons 3-6, encoding the QGSY-rich and first RGG region, or in exons 12-15, which encode the zinc finger domain, the other two RGG domains, and NLS. ${ }^{35}$ While these in the C-terminal have been shown to be functional, those in exons 3-6 are more commonly found in SALS or do not always segregate with disease, suggesting incomplete penetrance or nonpathogenic variations.

Previously, depletion of RNA polymerase II from the nucleus had been shown to lead to an increase of cytoplasmic FUS, suggesting that FUS had a role in transcription. ${ }^{38}$ It has subsequently been shown that FUS mediates the interaction between RNA polymerase II and the splicing factor U1 snRNP, thereby coupling transcription to splicing. ${ }^{39}$ Mutations in FUS lead to mislocalization of both FUS and U1 snRNP to the cytoplasm, ${ }^{40}$ and other RNA-binding proteins, including SMN1, hnRNPA1, and hnRNPA2, also colocalize in mtFUS aggregates. ${ }^{41}$ The consequence of these mtFUS interactions includes dysregulated splicing and an increased binding of FUS with SMN, leading to a reduction in Gem bodies, thereby representing both a loss and a gain of function by the mtFUS. ${ }^{42}$

FUS mutations may also confer pathogenicity via additional interactions. FUS has been shown to bind mRNAs and facilitate their transport down dendrites ${ }^{43}$ and subsequently has been shown to bind to the polyA tail of AMPA receptor GluA1, regulating its stability, with the loss of FUS leading to a reduction of GluA1. ${ }^{44}$ FUS has also been shown to translocate to the mitochondria through interaction with the mitochondrial chaperone heat shock protein 60 (HSP60) leading to mitochondrial damage. ${ }^{45}$ Finally, mtFUS interacts with Pur-alpha in SGs and increases phosphorylation of the elongation initiation factor 2-alpha, consequently inhibiting protein synthesis. ${ }^{46}$ However, the contribution of each of these interactions on disease pathogenesis remains to be determined.

\section{FTDALSI: C9ORF72 (C9ORF72)}

The most common cause of FALS to date is the expansion of an intronic GGGGCC repeat in C9ORF72. The region was originally identified through genome-wide association studies of SALS cases, as well as within the Finnish ALS population; ${ }^{47,48}$ while initial sequencing of the gene failed to identify any point mutations, targeted next-generation sequencing of the region established an intronic repeat region between the noncoding exons $1 \mathrm{a}$ and $1 \mathrm{~b} .{ }^{49,50}$ While healthy controls most commonly have $<10$ hexanucleotide repeats, individuals with ALS usually carry 400-2,000 repeats. The repeat expansion has been identified in $37.6 \%$ of FALS and $6.3 \%$ of SALS, as well as in up to $25.1 \%$ of familial FTD cases. ${ }^{51}$ Therefore, it is not surprising that the most significant clinical phenotype associated with this genetic subtype is an increased incidence of a family history of FTD. In addition, there is evidence that there are more bulbar onset cases 
associated with C9ORF72-related ALS (up to 44\%, compared to $25 \%-26 \%$ in non-C9ORF72 ALS), with some studies also reporting an earlier age of onset (by 1.8-5.0 years) and shorter disease duration (by 5.7-12.0 months). ${ }^{52}$

The function of the C9ORF72 gene is currently being determined, though structural analysis has established that there is similarity to "differentially expressed in normal and neoplasiclike proteins", which are GDP/GTP exchange factors regulating Rab-GTPases involved in vesicular trafficking. ${ }^{53}$ Further work demonstrated how C9ORF72 colocalized with Rab proteins involved in autophagy and endosomal trafficking. ${ }^{54}$ While the function is being established, several hypotheses have been proposed to explain how the intronic hexanucleotide repeat may cause neurodegeneration: 1) haploinsufficiency, 2) RNA toxicity, and 3) dipeptide repeat (DPR) protein toxicity.

\section{Haploinsufficiency}

Lower levels of C9ORF72 transcript were seen in patients with the repeat expansion compared to controls, and the haploinsufficiency hypothesis was supported when knockdown of the $C 9$ orf 72 homolog in zebrafish caused an axonal degeneration. ${ }^{55}$ In contrast, in a conditional C9orf72 knockout mouse, where C9orf72 was specifically ablated in neuronal cells, there was no evidence of a neurodegenerative phenotype. ${ }^{56}$ However, a systematic investigation of the expression levels of the three C9ORF72 transcripts (variant $1=$ exon 1a, $2-5$; variant 2 = exon 1 b, 2-11; variant $3=$ exon $1 \mathrm{a}, 2-11$ ) demonstrated significantly reduced expression of variants 1 and 2 in the cerebellum and frontal cortex of C9ORF72 expansion carriers, with a correlation between a higher level of expression of variant 1 and survival. ${ }^{57}$ This suggests that antisense oligomer strategies should avoid reducing C9ORF72 expression levels.

\section{RNA toxicity}

RNA foci were identified to be located primarily in the nucleus and occasionally in the cytoplasm of motor neurons and were found to be composed of both sense and antisense RNA. ${ }^{58}$ The presence of antisense RNA foci has been shown to be correlated with TDP-43 mislocalization ${ }^{59}$ but not DPRs. ${ }^{58}$ The repeat sequence is thought to form G-quadruplex structures within the cell. Many RNA-binding proteins colocalize with the RNA foci, potentially sequestering them from the cell and disrupting their RNA-processing functions. ${ }^{60,61}$ This may underlie the significant dysregulation of RNA splicing that is seen in the presence of the expansion, where greater disruption is present in patients with a shorter survival. ${ }^{62,63}$
However, RNA foci have been observed in fibroblasts from asymptomatic patients ${ }^{60,64}$ and in BAC transgenic mice containing an expanded allele; while RNA foci and DPRs recapitulate the neuropathology of ALS, there is no evidence of neurodegeneration. ${ }^{65,66}$ This is in contrast to a mouse expressing a 66-repeat G4C2 expansion specifically in the central nervous system, which exhibited neuropathological, behavioral, and motor deficits at 6 months. ${ }^{67}$

\section{DPR proteins}

Finally, it was demonstrated that the GGGGCC repeat expansion was subject to repeat-associated non-ATG translation. ${ }^{68}$ Both the sense and the antisense RNA are translated, forming DPR proteins composed of poly-GA, -GP, -GR, -PA, and -PR (with poly-GP generated from both antisense and sense RNA). ${ }^{58,69}$ These DPR proteins are found aggregated within the neuronal cytoplasmic inclusions and neuronal intranuclear inclusions in the motor cortex, cerebellum, hippocampus, and spinal cord, which also stain positive for ubiquitin and p62. Recently, antibodies raised against each of the DPR proteins have demonstrated that there is little correlation between DPR distribution/burden and clinical phenotype, ${ }^{70,71}$ which the authors suggest is evidence against DPR aggregation being a major pathogenic mechanism. This is in contrast to work using a Drosophila model, in which DPR expression caused neurodegeneration in the fly eye. ${ }^{72}$

In summary, there appears to be growing evidence supporting some form of RNA dysregulation as a contributing mechanism to C9ORF72-ALS. However, while different cellular and animal models using different constructs are generating conflicting results on the contribution of each of the three hypotheses, the precise mechanisms still remain to be fully elucidated. Disruption of C9ORF72 protein function in endosomal trafficking may also be a contributory factor.

\section{Other RNA-processing genes associated with ALS}

Prior to the identification of TARDBP and FUS as ALSassociated genes, two RNA-processing genes had already been implicated in ALS: angiogenin $(A N G)$ and senataxin (SETX). Subsequently, mutations in hnRNPA1 and matrin 3 (MATR3) have been identified through WES, and ataxin 2 (ATXN2) was identified as a risk factor.

\section{ALS9: angiogenin (ANG)}

Following the identification of the $A N G$ single-nucleotide polymorphism rs11701 as overrepresented in ALS cases 
from Scotland and Ireland, screening of $A N G$ identified seven missense mutations in 15 ALS cases, of which four were FALS (1.54\%) and eleven were SALS $(0.80 \%) .{ }^{73}$ ANG is a member of the pancreatic ribonuclease superfamily and is neuroprotective, while in mtANG this ability is impaired. ${ }^{74}$ While multiple mutations have been identified, p.K17I has not always shown disease segregation. However, a meta-analysis has demonstrated that Caucasian individuals carrying this allele have a 1.65 greater risk of ALS, which is increased to tenfold in FALS. ${ }^{75}$ ANG has also been shown to induce the assembly of SGs. ${ }^{76}$ Interestingly, this induction is inhibited by G-quadruplex structures, which are formed by the G4C2 C9ORF72 expanded repeat, thereby establishing a link between $C 9 O R F 72$ and $A N G$.

\section{ALS4: senataxin (SETX)}

Mutations in SETX are associated with the juvenile onset of ALS with distal muscle weakness and absence of bulbar or sensory symptoms. Patients typically have a long and slow disease progression with a relatively normal life span. ${ }^{77,78}$ Rare, AD mutations in SETX occur in ALS, while recessive SETX mutations are associated with ataxia-oculomotor apraxia-2. ${ }^{78}$ The mechanisms by which $S E T X$ variants lead to ALS is unknown; however, SETX encodes a DNA/RNA helicase protein proposed to play a role in DNA repair in response to oxidative stress. SETX also interacts with RNAprocessing proteins regulating transcription and pre-mRNA processing suggesting that the cause of motor neuron degeneration through SETX mutations is as a result of abnormal RNA processing. ${ }^{79}$

\section{ALSI3: ataxin 2 (ATXN2)}

More than 36 repeats of CAG within ATXN2 causes spinocerebellar ataxia 2; however, intermediate repeats of 27-33 were found to strongly associate with ALS having established that ATXN2 modifies TDP-43 toxicity in yeast. ${ }^{80}$ ATXN2 is an RNA-binding protein that is involved in RNA processing and localized to the ER, Golgi apparatus, and SGs; ATXN2 also interacts with FUS and intermediate expansions exacerbate the FUS mutant phenotype in cellular models. ${ }^{81}$ A recent meta-analysis of $>6,000$ ALS and 7,000 controls has identified that repeat lengths of 25-28 were actually protective, whereas the significant risk was associated with CAG repeats of $31-33 .{ }^{82}$ This finding is supported by an Italian study, where additionally $<31$ repeats were associated with spinal onset ALS and a shorter survival. ${ }^{83}$

\section{ALS20: heterogeneous nuclear ribonucleoprotein Al (hnRNPAl)}

Following the identification of hnRNPAl and hnRNPA2B1 mutations as causative in multisystem proteinopathy families using exome sequencing, these genes were specifically analyzed in 212 FALS for which exome sequencing was available. ${ }^{84} \mathrm{~A}$ single case was identified with a mutation in hnRNPA1. Interestingly, hnRNPA1 and A2/B1 are known interacting partners of TDP-43, and hnRNPA1 also interacts with ubiquilin-2. ${ }^{85}$ In ALS motor neurons, there is a loss of intense hnRNPA1 nuclear staining, which also correlates with nuclear loss of TDP-43, although hnRNPA1 was not seen to colocalize with TDP-43 in the skein-like inclusions. ${ }^{86}$ However, screening of 113 Italian FALS and 135 Dutch FALS and 1,084 Dutch SALS failed to find any hnRNPA1 mutations, suggesting that this is a very rare cause of FALS.

\section{ALS2 I: matrin 3 (MATR3)}

Exome sequencing of a large pedigree identified a mutation in the MATR3 gene; a previous family carrying a mutation in MATR3, originally diagnosed with AD distal, asymmetrical myopathy with vocal cord paralysis was reassessed and rediagnosed as having ALS. ${ }^{87}$ Further screening of Italian and British ALS cases identified a further two mutations: one FALS and one SALS. MATR3 is an RNA/DNA-binding protein that interacts with TDP-43; while the p.S85C mutation enhances this interaction, two other mutations, p.F115C and p.T22A, do not. However, this difference may underlie the slow progression of the disease in the family carrying the p.S85C mutation. While no further mutations were found in 372 FALS cases from France, Taiwan, Australia, and French Canada, four mutations were found in apparent SALS cases (three in French Canadians and one in a Taiwanese). ${ }^{88-91}$

\section{FET family genes}

The TATA box-binding protein-associated factor 15 (TAF15) and Ewing sarcoma breakpoint region 1 (EWSR1) are RNAbinding proteins and form the FET family of proteins along with FUS. All three contain prion-like domains, a feature used to rank potential RNA-binding proteins as being involved in ALS following a functional yeast screen. ${ }^{92}$ Screening of TAF15 identified five missense variants in 1,262 ALS cases, while screening of $E W S R 1$ identified two potential mutations among 817 ALS cases. ${ }^{93}$ While these variants were absent from controls, they were identified in patients with SALS, so segregation could not be demonstrated. However, both TAF15 and EWSR1 proteins show cytoplasmic mislocalization 
in SALS. Recently, whole-genome sequencing (WGS) identified an EWSR1 mutation in a set of monozygote twins disconcordant for ALS, suggesting that additional factors may influence disease. ${ }^{94}$

\section{Protein trafficking and degradation- related genes}

From the identification of the first gene for AR ALS, ALS2, combined with the presence of characteristic ubiquitinated inclusions in ALS motor neurons, dysregulation of protein trafficking and protein degradation has been implicated in the disease process. Mutations in genes involved in endosomal transport include alsin ( $A L S 2)$, vesicle-associated membrane protein (VAMP)-associated protein B $(V A P B)$, chromatin modifying protein $2 \mathrm{~B}(C H M P 2 B)$, and phosphoinositide 5-phosphatase (FIG4); those involved in the UPS include ubiquilin 2 (UBQLN2), sequestosome 1 (SQSTM1), and sigma nonopioid intracellular receptor 1 (SIGMARI), and autophagy is primarily implicated by mutations in optineurin $(O P T N)$, valosin-containing protein $(V C P)$, and tank-binding kinase 1 (TBK1). There is some overlap between these three biological pathways, which have also been implicated in SOD1- and C9ORF72-related ALS.

\section{ALS2: alsin (ALS2)}

The $A L S 2$ gene was originally identified through linkage analysis in consanguineous families from Tunisia and Saudi Arabia. ${ }^{95,96}$ The majority of the mutations lead to protein truncations, leading to a proposed loss of function. Alsin is thought to play a role in activating Rab5 GTPases. Rab5 is essential for endosomal trafficking, and in alsin knockout mice, neurons showed increased endosomal fusion and degradation but reduced mobility. ${ }^{97}$ One of the endosome components is the AMPA receptor GluR2, levels of which are reduced in alsin knockout mice. ${ }^{98}$

\section{ALS8: vesicle-associated membrane protein (VAMP)-associated protein B (VAPB)}

Linkage analysis of a large Brazilian family first established $V A P B$ as a causative gene for ALS, ${ }^{99}$ and the p.P56S mutation has been identified in multiple Brazilian pedigrees, indicative of a common founder. ${ }^{100}$ Additional mutations have been reported, though not all the variations found segregated with disease. ${ }^{101-104}$ VAPB is a type II integral ER membrane protein, involved in intracellular trafficking and the unfolded protein response ${ }^{105}$ and in regulating ER-mitochondria interactions. ${ }^{106}$ However, the p.P56S mutant protein was unable to initiate the unfolded protein response, altered calcium uptake into the mitochondria, and disrupted anterograde axonal transport of mitochondria. ${ }^{107-109}$

\section{ALS 17: chromatin modifying protein $2 B$ (CHMP2B)}

Mutations in $C H M P 2 B$ were initially identified in two probable FALS and a further three SALS cases; the majority had a predominant lower motor neuron phenotype. ${ }^{110,111}$ CHMP2B is a component of the ESCRT-III endosomal trafficking system, sorting cargos into multivesicular bodies. More recently, four novel mutations were identified in apparently sporadic ALS cases, and these were located in the domain required to form the multivesicular bodies. $^{2}$ In cellular models, mutant CHMP2B led to the formation of large vacuoles and an increase in autophagy marker LC3-II, implicating dysregulation of autophagy as a mechanism in ALS.

\section{ALSI I: phosphoinositide 5-phosphatase (FIG4)}

Mutations in FIG4 were originally identified as causative in Charcot-Marie-Tooth disease type 4J, though one family had a clinical phenotype resembling ALS. Screening of FALS and SALS cases identified nine variants, with six showing impaired function in yeast. ${ }^{12}$ FIG4, also known as $\mathrm{SAC} 3$, regulates $\mathrm{PI}(3,5) \mathrm{P}_{2}$ levels and thereby controls retrograde trafficking of endosomal vesicles to the Golgi. The mutant proteins showed loss of phosphatase activity, mislocalization, and inability to bind to the $\mathrm{PI}(3,5)$ $\mathrm{P}_{2}$ complex. Further screening in Italian and Taiwanese populations failed to find any novel variants, though only 80 SALS and 15 FALS were screened in each study. ${ }^{13,114}$ No pathological assessment was available on the mutation carriers; however, FIG4 was not shown to be mislocalized in SALS. ${ }^{115}$

\section{ALSI5: ubiquilin 2 (UBQLN2)}

$U B Q L N 2$ was identified by linkage analysis in a large multigenerational family. Screening of additional FALS cases with no male-to-male transmission found four further mutations; these were all located within the PXX repeat region of the protein. ${ }^{116}$ Additional screening identified further variants adjacent or within the PXX repeat region. ${ }^{117,118}$ Mutations have been shown to disrupt the protein degradation pathway through defective binding to the proteasome ${ }^{119}$ and causing mislocalization of OPTN from Rab-11-positive endosomal vesicles, ${ }^{120}$ as well as potentially impairing RNA metabolism, 
through loss of binding of UBQLN2 to hnRNP proteins, including hnRNPA $1 .{ }^{85}$

\section{FTDALS3: sequestosome I (SQSTMI)}

SQSTM1 or p62 is a ubiquitin-binding protein that plays a role in protein degradation via the proteasome and autophagy and is found within the characteristic ubiquitinated inclusions in patients with ALS. Screening of this gene found multiple mutations in both FALS and SALS cases. ${ }^{121}$ Further mutations were found in patients with ALS, some in association with Paget disease of bone, which is also known to be caused by SQSTM1 mutations. ${ }^{122,123}$ In a zebrafish model, where endogenous SQSTM1 was knocked-down, the fish showed behavioral and axonal abnormalities, as well as disrupted autophagy, as demonstrated by increased mTOR levels. ${ }^{124}$ Human SQSTM1 was able to rescue the phenotype, but the frequently found mutation, p.P392L, was unable to do so.

\section{ALSI6: sigma nonopioid intracellular receptor I (SIGMARI)}

Initially 3-UTR variants were identified within several AD FTDALS or FTD families and suggested that pathogenicity occurred through alteration of mRNA stability. ${ }^{125}$ However, using homozygosity mapping, a missense mutation in SIGMAR1 was subsequently found to segregate in a large consanguineous family with AR juvenile ALS (ARJALS). ${ }^{126}$ SIGMAR1 is an ER chaperone, a subunit of the ligandregulated potassium channel, and enables mitochondrial calcium transport via the IP3 receptor; mutation of SIGMARI causes the formation of cytoplasmic aggregations, a reduction in ATP production and subsequent decrease in proteasome activity. ${ }^{127}$ However, whether SIGMAR1 contributes to AD ALS is yet to be fully elucidated.

\section{ALSI2: optineurin (OPTN)}

Mutations in OPTN were originally identified through homozygosity mapping of consanguineous Japanese AR ALS families, which identified a homozygous exonic deletion and a homozygous nonsense mutation. ${ }^{128}$ Further screening of FALS cases identified two AD families heterozygous for a missense mutation. OPTN mediates its function through proteinprotein interactions; it binds to ubiquitin and UBQLN2, is an autophagy receptor (facilitating the recruitment of cargos to autophagosomes), is required for Golgi organization (as demonstrated by the Golgi fragmentation seen in postmortem spinal motor neurons), ${ }^{129}$ and also regulates NF- $\kappa$ B signaling. ${ }^{130}$ Subsequent screening has identified additional heterozygote mutations in SALS ${ }^{131}$ and AR ALS cases. ${ }^{132,133}$

\section{ALSI4: valosin-containing protein (VCP)}

Exome sequencing of a four-generation Italian family initially suggested mutation of $V C P$ as causative in ALS. ${ }^{134}$ Subsequently, a further four variants were identified in FALS cases, thereby providing further evidence that VCP is associated with ALS. VCP is an AAA+ (extended family of ATPases associated with various cellular activities) ATPase protein involved in a variety of cellular functions including mediating the proteasomal degradation of ubiquitinated protein in multimeric complexes and the targeting of substrates to autophagosomes. ${ }^{135}$ While screening failed to find any $V C P$ mutations in some populations, ${ }^{136-138}$ potential mutations were found in others and also in SALS cases. ${ }^{139,140}$ VCP mutations are also associated with inclusion body myopathy with early onset Paget Disease and frontotemporal dementia (IBMPFD), and patient fibroblasts have shown mitochondrial uncoupling and a reduction in ATP production, ${ }^{141}$ a feature also seen with SIGMAR1 mutations.

\section{FTDALS4: tank-binding kinase (TBKI)}

Mutations in $T B K 1$ were initially identified through exome sequencing of 2,874 ALS cases; dominant variants were found in $1.097 \%$ of cases and loss of function mutations in $0.382 \% .{ }^{142}$ This was shortly followed by a second paper in which sequencing of 252 FALS cases identified nine loss of function and four missense mutations. ${ }^{143}$ Mutations have subsequently been found in ALS, FTDALS, and FTD cases. ${ }^{144,145}$ TBK1 has a role in both innate immunity and NF- $\kappa B$ signaling, as well as in autophagy. TBK1 binds and phosphorylates ALS-related proteins OPTN and SQSTM1, whereas TBK1 mutants have been shown to no longer bind OPTN. ${ }^{143}$

\section{Impaired axonal transport and cytoskeletal dysfunction}

Neurons are extremely large cells that require transport of organelles, proteins, and RNA from the cell body down the axons. Molecular motors such as kinesins and dynein guide these cargos to microtubules to mediate anterograde and retrograde transport, respectively. While mutation of the p150 dynactin subunit in mice generated a neurodegenerative phenotype, mutations in this gene were not found in human ALS. ${ }^{146,147}$ However, exome sequencing has identified several cytoskeletal genes with mutations reported to be causative in ALS.

\section{ALS5: spatacsin (SPG I I)}

WES of two affected siblings from a nonconsanguineous family diagnosed with ARJALS identified only one gene, 
SPG11, in which variants were found in a compound heterozygous state. ${ }^{148}$ The involvement of the hereditary spastic paraparesis gene, normally associated with HSP with thin corpus callosum, had previously been implicated by a candidate gene screening of SPG11, in which mutations in 10 families with ARJALS were identified. ${ }^{149}$ While the exact function of the protein is unknown, iPSC-derived neuronal cells with SPG11 mutations demonstrated the protein colocalized with the cytoskeleton, and mutations caused axonal instability and impaired axonal transport. ${ }^{150}$

\section{ALSI8: profilin I (PFNI)}

Two multigenerational ALS families were determined to carry mutations in the PFN1 gene following WES. ${ }^{151}$ Extending the screen to additional FALS cases identified a further three mutations in five FALS cases and a p.E117G variant that was identified at very low frequency in controls. Further screening of ALS cases identified additional mutations and the variant. ${ }^{152-155}$ A meta-analysis subsequently determined that the p.E117G was associated with ALS and proposed this variant as a risk factor. ${ }^{156}$ The function of PFN1 is to convert monomeric actin to filamentous actin, and it is also found localized to SGs. ${ }^{157}$ It has been demonstrated that PFN1 mutations destabilize the protein, thereby leading to a loss of function, while the mutant protein is misfolded, thereby leading to a gain of function through aberrant protein interactions. ${ }^{158}$ However, the effect of the mutant protein on actin formation and SG dynamics is yet to be elucidated.

\section{ALS22: tubulin alpha 4A (TUBA4A)}

WES of 363 FALS index cases followed by rare variant burden identified five ALS cases with rare variants in TUBA4A; these included four missense mutations and one nonsense mutation, all of which were encoded in exon 4, in highly conserved amino acids, and absent from 4,300 exome variant server (EVS) controls. ${ }^{159}$ While further sequencing of ALS cases only identified one further variant, functional studies demonstrated that the $\mathrm{p}$.W407X nonsense mutant failed to localize to the microtubules, instead forming cytoplasmic inclusions, leading to disrupted microtubule assembly and stability, through a dominant-negative mechanism. Subsequent screening in the Chinese ALS population failed to identify any variants; ${ }^{160}$ data from other populations will undoubtedly emerge as further WES experiments are completed.

\section{Intermediate filament variants}

Cytoskeletal dysfunction is further implicated in the pathogenesis of ALS through rare variants being identified in intermediate filament genes. Neurofilaments (light, medium, and heavy) are the major structural components of the neuronal cytoskeleton and are present within the characteristic ubiquitinated protein inclusions. Candidate gene screening identified rare insertion/deletion variants in the KSP repeat domains of neurofilament heavy (NEFH) gene in SALS cases, ${ }^{161-163}$ while a single frameshift mutation has been identified in peripherin (PRPH1). ${ }^{164}$ However, the absence of mutations in known familial cases and ability to show segregation with disease has reduced the creditability of these genes as ALS loci.

\section{Additional loci}

Several additional ALS loci have been identified. Two loci are yet to have their associated genes identified: ALS3 on chr18q21 and ALS7 on chr20q13. ${ }^{165,166}$ A further two genes have been identified in FALS pedigrees, though their functional effects are currently predicted to disrupt neuronal development and mitochondrial function.

\section{ALSI 9: Erb-b2 receptor tyrosine kinase 4 (ERBB4)}

WGS of a Japanese AD ALS family identified a missense mutation in ERBB 4. ${ }^{167}$ Additional screening identified the same mutation in an unrelated Canadian family and a further mutation in a SALS case. ERBB4 is a receptor tyrosine kinase that is activated by neuregulin, resulting in autophosphorylation of the C-terminal. Mutations in ERBB4 reduced the level of autophosphorylation. ERBB4 was found to localize to $\mathrm{C}$-boutons, arising from interneurons, which synapse with spinal motor neurons. ${ }^{168}$ Interestingly, C-boutons are not found in oculomotor neurons, which are spared in ALS, while increases in neuregulin levels in $\mathrm{C}$-boutons increase during disease progression of the SOD1 G93A transgenic mice.

\section{FTDALS2: coiled-coil helix coiled-coil helix domain-containing protein I0 (CHCHD I0)}

CHCHD10 was initially associated with ALS through WES of a family exhibiting clinical features including ALS, FTD, cerebellar ataxia, and myopathy. ${ }^{169}$ This led to ALS and ALSFTD families being screened. Several additional mutations were found, ${ }^{170,171}$ though it became evident that the p.P34S mutation was nonpathogenic, as it was also found at similar frequencies in controls. ${ }^{172}$ The function of CHCHD10 is unknown; it localizes to the mitochondria. Fibroblasts from family members of the original pedigree showed multiple mitochondrial DNA deletions, respiratory chain defects, and structurally abnormal mitochondria, suggesting that CHCHD10 may have a role in the respiratory chain and/or in mitochondrial genome stability. ${ }^{169}$ This has been supported 
by additional work by Genin et al, ${ }^{173}$ which found not only a loss of cristae and mitochondrial genome repair in patient fibroblasts but also a failure of apoptosis due to an inability to release cytochrome $\mathrm{C}$.

\section{Conclusion}

ALS genetics is having a significant impact on our understanding of the disease and the mechanisms implicated in neurodegeneration. The majority of genes encode proteins involved in RNA processing and the protein degradation pathways, UPS, and autophagy. However, neither of these nor the other pathways implicated work in isolation but

Table 2 Clinical phenotypes also associated with ALS genes

\begin{tabular}{|c|c|c|c|}
\hline ALS loci & $\begin{array}{l}\text { Gene } \\
\text { name }\end{array}$ & $\begin{array}{l}\text { Alternative clinical } \\
\text { phenotypes }\end{array}$ & Inheritance \\
\hline \multirow[t]{2}{*}{ ALS2 } & ALS2 & $\begin{array}{l}\text { Primary lateral sclerosis, } \\
\text { juvenile (PLSJ) }\end{array}$ & AR \\
\hline & & $\begin{array}{l}\text { Spastic paralysis, infantile onset } \\
\text { ascending (IAHSP) }\end{array}$ & AR \\
\hline ALS4 & SETX & $\begin{array}{l}\text { Spinocerebellar ataxia, } \\
\text { autosomal recessive I (SCARI) }\end{array}$ & $A R$ \\
\hline \multirow[t]{2}{*}{ ALS5 } & SPGII & Spastic paraplegia II (SPGII) & $A R$ \\
\hline & & $\begin{array}{l}\text { Charcot-Marie-Tooth disease, } \\
\text { axonal, type } 2 X(\text { CMT } 2 X)\end{array}$ & $A R$ \\
\hline ALS6 & FUS & $\begin{array}{l}\text { Tremor, hereditary essential } 4 \\
\text { (ETM4) }\end{array}$ & $A D$ \\
\hline ALS8 & VAPB & $\begin{array}{l}\text { Spinal muscular atrophy (SMA), } \\
\text { late onset, Finkel type (SMAFK) }\end{array}$ & $A D$ \\
\hline \multirow[t]{3}{*}{ ALSII } & FIG4 & CMT4J & $A R$ \\
\hline & & Yunis-Varon syndrome & $A R$ \\
\hline & & $\begin{array}{l}\text { Polymicrogyria, bilateral } \\
\text { temporooccipital (BTOP) }\end{array}$ & $A R$ \\
\hline ALSI2 & OPTN & $\begin{array}{l}\text { Glaucoma, primary open angle } \\
\text { (POAG) }\end{array}$ & $A D$ \\
\hline ALSI3 & ATXN2 & $\begin{array}{l}\text { Spinocerebellar ataxia } 2 \\
\text { (SCA2) }\end{array}$ & $A D$ \\
\hline ALSI4 & $V C P$ & $\begin{array}{l}\text { CMT2Y } \\
\text { Inclusion body myopathy with } \\
\text { early onset Paget disease and } \\
\text { frontotemporal dementia I } \\
\text { (IBMPFDI) }\end{array}$ & $\begin{array}{l}A D \\
A D\end{array}$ \\
\hline ALSI6 & SIGMARI & $\begin{array}{l}\text { SMA, distal, autosomal } \\
\text { recessive } 2 \text { (DSMA2) }\end{array}$ & $A R$ \\
\hline ALSI7 & CHMP2B & $\begin{array}{l}\text { Frontotemporal dementia, } \\
\text { Chr 3-linked (FTD3) }\end{array}$ & $A D$ \\
\hline ALS20 & hnRNPAI & IBMPFD3 & $A D$ \\
\hline \multirow[t]{2}{*}{ FTDALS2 } & CHCHDI & SMA, Jokela type (SMAJ) & $A D$ \\
\hline & & $\begin{array}{l}\text { Myopathy isolated } \\
\text { mitochondrial, autosomal } \\
\text { dominant (IMMD) }\end{array}$ & $A D$ \\
\hline FTDALS3 & SQSTMI & Paget disease of bone 3 (PDB3) & $A D$ \\
\hline
\end{tabular}

Notes: Data obtained from gene-phenotype relationship data available in Online Mendelian Inheritance in Man, $\mathrm{OMIM}^{\circledR}$. McKusick-Nathans Institute of Genetic Medicine, Johns Hopkins University; Baltimore, MD, USA. Available at: http://omim. org/. Accessed March 16, $2016 .^{3}$

Abbreviations: ALS, amyotrophic lateral sclerosis; FTD, frontotemporal dementia; $A R$, autosomal recessive; $A D$, autosomal dominant. impact on other cellular processes. The proposed mechanisms are mutually compatible, and it is most likely that multiple dysregulated pathways contribute to the loss of motor neurons. This is clearly demonstrated by TDP-43, an RNA-binding protein, that is mislocalized from the nucleus, thereby causing loss of nuclear function, and is aggregated in the cytoplasm as a component of the characteristic ubiquitinated inclusions.

Along with multiple genetic causes, it is clear that these genes are also implicated in additional disorders, not only in other neurodegenerative disorders such as FTD, HSP, and ataxia, but also in myopathies, Paget disease of bone, and glaucoma (Table 2). The use of WES or WGS, in projects such as the 100,000 Genomes Project in the UK (www.genomicsengland.co.uk), or Project Mine among the International ALS community (www.projectmine.com), will potentially enable a greater understanding of why mutations in a gene in one family present with a specific clinical phenotype, while another family shows a different disease.

WES and WGS will also further our understanding of the impact of oligogenic inheritance in ALS. While family pedigrees clearly show inheritance in an $\mathrm{AD}$ manner for classical ALS, the move away from analyzing a single gene at a time has highlighted evidence of mutations in multiple ALS genes in some patients. ${ }^{2}$ Screening of a large ALS cohort demonstrated that $14 \%$ of FALS and $2.6 \%$ of SALS cases had more than one potential pathogenic mutation in a known ALS gene, and these cases had a significantly earlier onset of disease. ${ }^{174}$ This also highlights the fact that apparent SALS cases also carry genetic mutations, as has been evidenced by the identification of de novo mutations in SALS cases following WES of trios comprising of an ALS patient and their two unaffected parents. ${ }^{175,176}$ While in some cases, these may actually be rare AR mutations, additional WES and WGS sequencing of cases will allow the genetic contribution in SALS, estimated to be $61 \%,{ }^{177}$ to be elucidated.

\section{Acknowledgments}

JK and RW are funded by STRENGTH. This is an EU Joint Programme - Neurodegenerative Disease Research (JPND) project. The project is supported through the following funding organizations under the aegis of JPND - www.jpnd.eu: Belgium, The National Funds for Scientific Research (F.R.S. FNRS); France, Agence Nationale de la Recherche (ANR); Germany, Bundesministerium für Bildung und Forschung (BMBF); Italy, Ministero della Salute; Italy, Ministero dell'Istruzione, dell'Università e della Ricerca (MIUR); The Netherlands, The Netherlands Organisation for Health Research and Development (ZonMw); Sweden, Swedish Research Council (VR); Switzerland, Schweizerischer 
Nationalfonds zur Förderung der wissenschaftlichen Forschung (SNF); and United Kingdom, Medical Research Council (MRC).

JK is also funded by SOPHIA. This is an EU Joint Programme - Neurodegenerative Disease Research (JPND) project. The project is supported through the following funding organizations under the aegis of JPND - www.jpnd.eu: France, Agence Nationale de la Recherche (ANR); Germany, Bundesministerium für Bildung und Forschung (BMBF); Ireland, Health Research Board (HRB); Italy, Ministero della Salute; The Netherlands, The Netherlands Organisation for Health Research and Development (ZonMw); Poland, Narodowe Centrum Badań i Rozwoju; Portugal, Fundação a Ciência e a Tecnologia; Spain, Ministerio de Ciencia e Innovación; Switzerland, Schweizerischer Nationalfonds zur Förderung der wissenschaftlichen Forschung (SNF); Turkey, Tübitak; and United Kingdom, Medical Research Council (MRC).

JK receives funding from the European Community's Seventh Framework Programme (FP7/2007-2013) under the EuroMOTOR project, grant agreement no 259867 and from the European Horizon 2020 research and innovation program under grant agreement no 633413.

AAS is funded by a PhD Scholarship from the University of Dhammam, Saudi Arabia.

\section{Disclosure}

The authors report no conflicts of interest in this work.

\section{References}

1. Cooper-Knock J, Jenkins T, Shaw PJ. Clinical and molecular aspects of motor neuron disease. Colloq Series Genomic Mol Med. 2013;2:1-60.

2. van Blitterswijk M, van Es MA, Hennekam EA, et al. Evidence for an oligogenic basis of amyotrophic lateral sclerosis. Hum Mol Genet. 2012;21:3776-3784.

3. Online Mendelian Inheritance in Man, OMIM ${ }^{\circledR}$. McKusick-Nathans Institute of Genetic Medicine, Johns Hopkins University; Baltimore, MD, USA. Available at: http://omim.org/. Accessed March 16, 2016.

4. Rosen DR, Siddique T, Patterson D, et al. Mutations in Cu/Zn superoxide dismutase gene are associated with familial amyotrophic lateral sclerosis. Nature. 1993;362:59-62.

5. Andersen PM. Amyotrophic lateral sclerosis associated with mutations in the CuZn superoxide dismutase gene. Curr Neurol Neurosci Rep. 2006;6:37-46.

6. Abel O, Powell JF, Andersen PM, Al-Chalabi A. ALSoD: a user-friendly online bioinformatics tool for amyotrophic lateral sclerosis genetics. Hum Mutat. 2012;33:1345-1351.

7. Felbecker A, Camu W, Valdmanis PN, et al. Four familial ALS pedigrees discordant for two SOD1 mutations: are all SOD1 mutations pathogenic? J Neurol Neurosurg Psychiatry. 2010;81:572-577.

8. Marangi G, Traynor BJ. Genetic causes of amyotrophic lateral sclerosis: new genetic analysis methodologies entailing new opportunities and challenges. Brain Res. 2015;1607:75-93.

9. Kaur SJ, McKeown S, Rashid S. Mutant SOD1 mediated pathogenesis of amyotrophic lateral sclerosis. Gene. 2016;577(2):109-118.
10. Sheng Y, Chattopadhyay M, Whitelegge J, Valentine JS. SOD1 aggregation and ALS: role of metallation states and disulfide status. Curr Top Med Chem. 2012;12:2560-2572.

11. Grad LI, Pokrishevsky E, Silverman JM, Cashman NR. Exosomedependent and independent mechanisms are involved in prion-like transmission of propagated $\mathrm{Cu} / \mathrm{Zn}$ superoxide dismutase misfolding. Prion. 2014;8:331-335.

12. Munch C, Bertolotti A. Self-propagation and transmission of misfolded mutant SOD1: prion or prion-like phenomenon? Cell Cycle. 2011; 10:1711.

13. Ayers JI, Fromholt SE, O'Neal VM, Diamond JH, Borchelt DR. Prion-like propagation of mutant SOD1 misfolding and motor neuron disease spread along neuroanatomical pathways. Acta Neuropathol. 2016;131(1):103-114.

14. Kabashi E, Agar JN, Strong MJ, Durham HD. Impaired proteasome function in sporadic amyotrophic lateral sclerosis. Amyotroph Lateral Scler. 2012;13:367-371.

15. Kabashi E, Durham HD. Failure of protein quality control in amyotrophic lateral sclerosis. Biochim Biophys Acta. 2006;1762:1038-1050.

16. Kalmar B, Lu CH, Greensmith L. The role of heat shock proteins in amyotrophic lateral sclerosis: the therapeutic potential of Arimoclomol. Pharmacol Ther. 2014;141:40-54.

17. Sreedharan J, Blair IP, Tripathi VB, et al. TDP-43 mutations in familial and sporadic amyotrophic lateral sclerosis. Science. 2008;319: 1668-1672.

18. Millecamps S, Salachas F, Cazeneuve C, et al. SOD1, ANG, VAPB, TARDBP, and FUS mutations in familial amyotrophic lateral sclerosis: genotype-phenotype correlations. J Med Genet. 2010;47:554-560.

19. Baralle M, Buratti E, Baralle FE. The role of TDP-43 in the pathogenesis of ALS and FTLD. Biochem Soc Trans. 2013;41:1536-1540.

20. Lagier-Tourenne C, Polymenidou M, Cleveland DW. TDP-43 and FUS/ TLS: emerging roles in RNA processing and neurodegeneration. Hum Mol Genet. 2010;19:R46-R64.

21. Ignatius SH, Wu F, Harrich D, Garciamartinez LF, Gaynor RB. Cloning and characterization of a novel cellular protein, Tdp-43, that binds to human-immunodeficiency-virus type-1 Tar DNA-sequence motifs. J Virol. 1995;69:3584-3596.

22. Scotter EL, Chen HJ, Shaw CE. TDP-43 proteinopathy and ALS: insights into disease mechanisms and therapeutic targets. Neurotherapeutics. 2015;12:515-518.

23. Ayala YM, De Conti L, Avendano-Vazquez SE, et al. TDP-43 regulates its mRNA levels through a negative feedback loop. EMBO J. 2011; 30:277-288.

24. Polymenidou M, Lagier-Tourenne C, Hutt KR, et al. Long pre-mRNA depletion and RNA missplicing contribute to neuronal vulnerability from loss of TDP-43. Nat Neurosci. 2011;14:459-468.

25. Sephton CF, Cenik C, Kucukural A, et al. Identification of neuronal RNA targets of TDP-43-containing ribonucleoprotein complexes. J Biol Chem. 2011;286:1204-1215.

26. Xiao S, Sanelli T, Dib S, et al. RNA targets ofTDP-43 identified by UVCLIP are deregulated in ALS. Mol Cell Neurosci. 2011;47:167-180.

27. Ling JP, Pletnikova O, Troncoso JC, Wong PC. TDP-43 repression of nonconserved cryptic exons is compromised in ALS-FTD. Science. 2015;349:650-655.

28. Aulas A, Vande Velde C. Alterations in stress granule dynamics driven by TDP-43 and FUS: a link to pathological inclusions in ALS? Front Cell Neurosci. 2015;9:423.

29. Neumann M, Sampathu DM, Kwong LK, et al. Ubiquitinated TDP-43 in frontotemporal lobar degeneration and amyotrophic lateral sclerosis. Science. 2006;314:130-133.

30. Qin H, Lim LZ, Wei Y, Song J. TDP-43 N terminus encodes a novel ubiquitin-like fold and its unfolded form in equilibrium that can be shifted by binding to ssDNA. Proc Natl Acad Sci USA. 2014;111:18619-18624.

31. Highley JR, Kirby J, Jansweijer JA, et al. Loss of nuclear TDP-43 in amyotrophic lateral sclerosis (ALS) causes altered expression of splicing machinery and widespread dysregulation of RNA splicing in motor neurones. Neuropathol Appl Neurobiol. 2014;40:670-685. 
32. De Conti L, Akinyi MV, Mendoza-Maldonado R, Romano M, Baralle M, Buratti E. TDP-43 affects splicing profiles and isoform production of genes involved in the apoptotic and mitotic cellular pathways. Nucleic Acids Res. 2015;43:8990-9005.

33. Amlie-Wolf A, Ryvkin P, Tong R, et al. Transcriptomic changes due to cytoplasmic TDP-43 expression reveal dysregulation of histone transcripts and nuclear chromatin. PLoS One. 2015;10:e0141836.

34. Feiler MS, Strobel B, Freischmidt A, et al. TDP-43 is intercellularly transmitted across axon terminals. J Cell Biol. 2015;211:897-911.

35. Deng H, Gao K, Jankovic J. The role of FUS gene variants in neurodegenerative diseases. Nat Rev Neurol. 2014;10:337-348.

36. Kwiatkowski TJ Jr, Bosco DA, Leclerc AL, et al. Mutations in the FUS/TLS gene on chromosome 16 cause familial amyotrophic lateral sclerosis. Science. 2009;323:1205-1208.

37. Vance C, Rogelj B, Hortobagyi T, et al. Mutations in FUS, an RNA processing protein, cause familial amyotrophic lateral sclerosis type 6 . Science. 2009;323:1208-1211

38. Zinszner H, Sok J, Immanuel D, Yin Y, Ron D. TLS (FUS) binds RNA in vivo and engages in nucleo-cytoplasmic shuttling. J Cell Sci. 1997;110(pt 15):1741-1750.

39. Yu Y, Reed R. FUS functions in coupling transcription to splicing by mediating an interaction between RNAP II and U1 snRNP. Proc Natl Acad Sci U S A. 2015;112:8608-8613.

40. Yu Y, Chi B, Xia W, et al. U1 snRNP is mislocalized in ALS patient fibroblasts bearing NLS mutations in FUS and is required for motor neuron outgrowth in zebrafish. Nucleic Acids Res. 2015;43: 3208-3218.

41. Takanashi K, Yamaguchi A. Aggregation of ALS-linked FUS mutant sequesters RNA binding proteins and impairs RNA granules formation. Biochem Biophys Res Commun. 2014;452:600-607.

42. Sun S, Ling SC, Qiu J, et al. ALS-causative mutations in FUS/TLS confer gain and loss of function by altered association with SMN and U1-snRNP. Nat Commun. 2015;6:6171.

43. Fujii R, Takumi T. TLS facilitates transport of mRNA encoding an actin-stabilizing protein to dendritic spines. J Cell Sci. 2005;118: 5755-5765.

44. Udagawa T, Fujioka Y, Tanaka M, et al. FUS regulates AMPA receptor function and FTLD/ALS-associated behaviour via GluA1 mRNA stabilization. Nat Commun. 2015;6:7098.

45. Deng J, Yang M, Chen Y, et al. FUS interacts with HSP60 to promote mitochondrial damage. PLoS Genet. 2015;11:e1005357.

46. Di Salvio M, Piccinni V, Gerbino V, et al. Pur-alpha functionally interacts with FUS carrying ALS-associated mutations. Cell Death Dis. 2015;6:e1943.

47. Shatunov A, Mok K, Newhouse S, et al. Chromosome 9p21 in sporadic amyotrophic lateral sclerosis in the UK and seven other countries: a genome-wide association study. Lancet Neurol. 2010;9:986-994.

48. Laaksovirta H, Peuralinna T, Schymick JC, et al. Chromosome 9p21 in amyotrophic lateral sclerosis in Finland: a genome-wide association study. Lancet Neurol. 2010;9:978-985.

49. Renton AE, Majounie E, Waite A, et al. A hexanucleotide repeat expansion in C9ORF72 is the cause of chromosome 9p21-linked ALS-FTD. Neuron. 2011;72:257-268.

50. DeJesus-Hernandez M, Mackenzie IR, Boeve BF, et al. Expanded GGGGCC hexanucleotide repeat in noncoding region of C9ORF72 causes chromosome 9p-linked FTD and ALS. Neuron. 2011;72: 245-256.

51. Majounie E, Renton AE, Mok K, et al. Frequency of the C9orf72 hexanucleotide repeat expansion in patients with amyotrophic lateral sclerosis and frontotemporal dementia: a cross-sectional study. Lancet Neurol. 2012;11:323-330.

52. Cooper-Knock J, Kirby J, Highley R, Shaw PJ. The spectrum of C9orf72-mediated neurodegeneration and amyotrophic lateral sclerosis. Neurotherapeutics. 2015;12:326-339.

53. Levine TP, Daniels RD, Gatta AT, Wong LH, Hayes MJ. The product of C9orf72, a gene strongly implicated in neurodegeneration, is structurally related to DENN Rab-GEFs. Bioinformatics. 2013;29:499-503.
54. Farg MA, Sundaramoorthy V, Sultana JM, et al. C9ORF72, implicated in amyotrophic lateral sclerosis and frontotemporal dementia, regulates endosomal trafficking. Hum Mol Genet. 2014;23:3579-3595.

55. Ciura S, Lattante S, Le Ber I, et al. Loss of function of C9orf72 causes motor deficits in a zebrafish model of amyotrophic lateral sclerosis. Ann Neurol. 2013;74:180-187.

56. Koppers M, Blokhuis AM, Westeneng HJ, et al. C9orf72 ablation in mice does not cause motor neuron degeneration or motor deficits. Ann Neurol. 2015;78:426-438.

57. van Blitterswijk M, Gendron TF, Baker MC, et al. Novel clinical associations with specific C9ORF72 transcripts in patients with repeat expansions in C9ORF72. Acta Neuropathol. 2015;130:863-876.

58. Gendron TF, Bieniek KF, Zhang YJ, et al. Antisense transcripts of the expanded C9ORF72 hexanucleotide repeat form nuclear RNA foci and undergo repeat-associated non-ATG translation in c9FTD/ALS Acta Neuropathol. 2013;126:829-844.

59. Cooper-Knock J, Higginbottom A, Stopford MJ, et al. Antisense RNA foci in the motor neurons of C9ORF72-ALS patients are associated with TDP-43 proteinopathy. Acta Neuropathol. 2015;130:63-75.

60. Cooper-Knock J, Walsh MJ, Higginbottom A, et al. Sequestration of multiple RNA recognition motif-containing proteins by $\mathrm{C} 9$ orf72 repeat expansions. Brain. 2014;137:2040-2051.

61. Lee YB, Chen HJ, Peres JN, et al. Hexanucleotide repeats in ALS/FTD form length-dependent RNA foci, sequester RNA binding proteins, and are neurotoxic. Cell Rep. 2013;5:1178-1186.

62. Cooper-Knock J, Bury JJ, Heath PR, et al. C9ORF72 GGGGCC expanded repeats produce splicing dysregulation which correlates with disease severity in amyotrophic lateral sclerosis. PLoS One. 2015;10:e0127376.

63. Prudencio M, Belzil VV, Batra R, et al. Distinct brain transcriptome profiles in C9orf72-associated and sporadic ALS. Nat Neurosci. 2015;18:1175-1182.

64. Lagier-Tourenne C, Baughn M, Rigo F, et al. Targeted degradation of sense and antisense C9orf72 RNA foci as therapy for ALS and frontotemporal degeneration. Proc Natl Acad Sci U S A. 2013;110: E4530-E4539.

65. Peters OM, Cabrera GT, Tran H, et al. Human C9ORF72 hexanucleotide expansion reproduces RNA foci and dipeptide repeat proteins but not neurodegeneration in BAC transgenic mice. Neuron. 2015;88:902-909.

66. O’Rourke JG, Bogdanik L, Muhammad AK, et al. C9orf72 BAC transgenic mice display typical pathologic features of ALS/FTD. Neuron. 2015;88:892-901.

67. Chew J, Gendron TF, Prudencio M, et al. Neurodegeneration. C9ORF72 repeat expansions in mice cause TDP-43 pathology, neuronal loss, and behavioral deficits. Science. 2015;348:1151-1154.

68. Mori K, Weng SM, Arzberger T, et al. The C9orf72 GGGGCC repeat is translated into aggregating dipeptide-repeat proteins in FTLD/ALS. Science. 2013;339:1335-1338.

69. Mori K, Arzberger T, Grasser FA, et al. Bidirectional transcripts of the expanded $\mathrm{C} 9$ orf 72 hexanucleotide repeat are translated into aggregating dipeptide repeat proteins. Acta Neuropathol. 2013;126:881-893.

70. Mackenzie IR, Frick P, Grasser FA, et al. Quantitative analysis and clinico-pathological correlations of different dipeptide repeat protein pathologies in C9ORF72 mutation carriers. Acta Neuropathol. 2015;130: 845-861.

71. Davidson Y, Robinson AC, Liu X, et al. Neurodegeneration in frontotemporal lobar degeneration and motor neurone disease associated with expansions in C9orf72 is linked to TDP-43 pathology and not associated with aggregated forms of dipeptide repeat proteins. Neuropathol Appl Neurobiol. Epub 2015 Nov 5.

72. Mizielinska S, Gronke S, Niccoli T, et al. C9orf72 repeat expansions cause neurodegeneration in Drosophila through arginine-rich proteins. Science. 2014;345:1192-1194.

73. Greenway MJ, Andersen PM, Russ C, et al. ANG mutations segregate with familial and 'sporadic' amyotrophic lateral sclerosis. Nat Genet. 2006;38:411-413. 
74. Subramanian V, Crabtree B, Acharya KR. Human angiogenin is a neuroprotective factor and amyotrophic lateral sclerosis associated angiogenin variants affect neurite extension/path finding and survival of motor neurons. Hum Mol Genet. 2008;17:130-149.

75. Pan L, Deng X, Ding D, Leng H, Zhu X, Wang Z. Association between the Angiogenin (ANG) K17I variant and amyotrophic lateral sclerosis risk in Caucasian: a meta-analysis. Neurol Sci. 2015;36(12):2163-2168.

76. Ivanov P, O’Day E, Emara MM, Wagner G, Lieberman J, Anderson P. G-quadruplex structures contribute to the neuroprotective effects of angiogenin-induced tRNA fragments. Proc Natl Acad Sci U S A. 2014;111:18201-18206.

77. Chen YZ, Bennett CL, Huynh HM, et al. DNA/RNA helicase gene mutations in a form of juvenile amyotrophic lateral sclerosis (ALS4). Am J Hum Genet. 2004;74:1128-1135.

78. Hirano M, Quinzii CM, Mitsumoto H, et al. Senataxin mutations and amyotrophic lateral sclerosis. Amyotroph Lateral Scler. 2011;12: 223-227.

79. Skourti-Stathaki K, Proudfoot NJ, Gromak N. Human senataxin resolves RNA/DNA hybrids formed at transcriptional pause sites to promote Xrn2-dependent termination. Mol Cell. 2011;42:794-805.

80. Elden AC, Kim HJ, Hart MP, et al. Ataxin-2 intermediate-length polyglutamine expansions are associated with increased risk for ALS. Nature. 2010;466:1069-1075.

81. Farg MA, Soo KY, Warraich ST, Sundaramoorthy V, Blair IP, Atkin JD. Ataxin-2 interacts with FUS and intermediate-length polyglutamine expansions enhance FUS-related pathology in amyotrophic lateral sclerosis. Hum Mol Genet. 2013;22:717-728.

82. Neuenschwander AG, Thai KK, Figueroa KP, Pulst SM. Amyotrophic lateral sclerosis risk for spinocerebellar ataxia type 2 ATXN2 CAG repeat alleles: a meta-analysis. JAMA Neurol. 2014;71:1529-1534.

83. Borghero G, Pugliatti M, Marrosu F, et al; ITALSGEN and SARDINALS consortia. ATXN2 is a modifier of phenotype in ALS patients of Sardinian ancestry. Neurobiol Aging. 2015;36:2906. e1-2906.e15.

84. Kim HJ, Kim NC, Wang YD, et al. Mutations in prion-like domains in hnRNPA2B1 and hnRNPA1 cause multisystem proteinopathy and ALS. Nature. 2013;495:467-473.

85. Gilpin KM, Chang L, Monteiro MJ. ALS-linked mutations in ubiquilin-2 or hnRNPA1 reduce interaction between ubiquilin-2 and hnRNPA1. Hum Mol Genet. 2015;24:2565-2577.

86. Honda H, Hamasaki H, Wakamiya T, et al. Loss of hnRNPA1 in ALS spinal cord motor neurons with TDP-43-positive inclusions. Neuropathology. 2015;35:37-43.

87. Johnson JO, Pioro EP, Boehringer A, et al; ITALSGEN Consortium. Mutations in the Matrin 3 gene cause familial amyotrophic lateral sclerosis. Nat Neurosci. 2014;17:664-666.

88. Fifita JA, Williams KL, McCann EP, et al. Mutation analysis of MATR3 in Australian familial amyotrophic lateral sclerosis. Neurobiol Aging. 2015;36:1602.e1-1602.e12.

89. Lin KP, Tsai PC, Liao YC, et al. Mutational analysis of MATR3 in Taiwanese patients with amyotrophic lateral sclerosis. Neurobiol Aging. 2015;36:2005.e1-2005.e4.

90. Leblond CS, Gan-Or Z, Spiegelman D, et al. Replication study of MATR3 in familial and sporadic amyotrophic lateral sclerosis. Neurobiol Aging. 2016;37:209.e17-21.

91. Millecamps S, De Septenville A, Teyssou E, et al; French research network on FTD and FTD-ALS. Genetic analysis of matrin 3 gene in French amyotrophic lateral sclerosis patients and frontotemporal lobar degeneration with amyotrophic lateral sclerosis patients. Neurobiol Aging. 2014;35(12):2882.e13-15.

92. Couthouis J, Hart MP, Shorter J, et al. A yeast functional screen predicts new candidate ALS disease genes. Proc Natl Acad Sci U S A. 2011;108:20881-20890

93. Couthouis J, Hart MP, Erion R, et al. Evaluating the role of the FUS/ TLS-related gene EWSR1 in amyotrophic lateral sclerosis. Hum Mol Genet. 2012;21:2899-2911.
94. Meltz Steinberg K, Nicholas TJ, Koboldt DC, Yu B, Mardis E, Pamphlett R. Whole genome analyses reveal no pathogenetic single nucleotide or structural differences between monozygotic twins discordant for amyotrophic lateral sclerosis. Amyotroph Lateral Scler Frontotemporal Degener. 2015;16:385-392.

95. Hadano S, Hand CK, Osuga H, et al. A gene encoding a putative GTPase regulator is mutated in familial amyotrophic lateral sclerosis 2 . Nat Genet. 2001;29:166-173.

96. Yang Y, Hentati A, Deng HX, et al. The gene encoding alsin, a protein with three guanine-nucleotide exchange factor domains, is mutated in a form of recessive amyotrophic lateral sclerosis. Nat Genet. 2001;29:160-165.

97. Lai C, Xie C, Shim H, Chandran J, Howell BW, Cai H. Regulation of endosomal motility and degradation by amyotrophic lateral sclerosis 2/alsin. Mol Brain. 2009;2:23.

98. Lai C, Xie C, McCormack SG, et al. Amyotrophic lateral sclerosis 2-deficiency leads to neuronal degeneration in amyotrophic lateral sclerosis through altered AMPA receptor trafficking. J Neurosci. 2006;26:11798-11806.

99. Nishimura AL, Mitne-Neto M, Silva HC, et al. A mutation in the vesicle-trafficking protein VAPB causes late-onset spinal muscular atrophy and amyotrophic lateral sclerosis. Am J Hum Genet. 2004; $75: 822-831$.

100. Nishimura AL, Al-Chalabi A, Zatz M. A common founder for amyotrophic lateral sclerosis type 8 (ALS8) in the Brazilian population. Hum Genet. 2005;118:499-500.

101. Chen HJ, Anagnostou G, Chai A, et al. Characterization of the properties of a novel mutation in VAPB in familial amyotrophic lateral sclerosis. J Biol Chem. 2010;285:40266-40281.

102. Kabashi E, El Oussini H, Bercier V, et al. Investigating the contribution of VAPB/ALS8 loss of function in amyotrophic lateral sclerosis. Hum Mol Genet. 2013;22:2350-2360.

103. Ingre $\mathrm{C}$, Pinto $\mathrm{S}$, Birve $\mathrm{A}$, et al. No association between VAPB mutations and familial or sporadic ALS in Sweden, Portugal and Iceland. Amyotroph Lateral Scler Frontotemporal Degener. 2013;14:620-627.

104. van Blitterswijk M, van Es MA, Koppers M, et al. VAPB and C9orf72 mutations in 1 familial amyotrophic lateral sclerosis patient. Neurobiol Aging. 2012;33:2950.e1-2950.e4.

105. Lev S, Ben Halevy D, Peretti D, Dahan N. The VAP protein family: from cellular functions to motor neuron disease. Trends Cell Biol. 2008;18:282-290.

106. Stoica R, De Vos KJ, Paillusson S, et al. ER-mitochondria associations are regulated by the VAPB-PTPIP51 interaction and are disrupted by ALS/FTD-associated TDP-43. Nat Commun. 2014;5:3996.

107. De Vos KJ, Morotz GM, Stoica R, et al. VAPB interacts with the mitochondrial protein PTPIP51 to regulate calcium homeostasis. Hum Mol Genet. 2012;21:1299-1311.

108. Morotz GM, De Vos KJ, Vagnoni A, Ackerley S, Shaw CE, Miller CC. Amyotrophic lateral sclerosis-associated mutant VAPBP56S perturbs calcium homeostasis to disrupt axonal transport of mitochondria. Hum Mol Genet. 2012;21:1979-1988.

109. Kanekura K, Nishimoto I, Aiso S, Matsuoka M. Characterization of amyotrophic lateral sclerosis-linked P56S mutation of vesicleassociated membrane protein-associated protein B (VAPB/ALS8). J Biol Chem. 2006;281:30223-30233

110. Parkinson N, Ince PG, Smith MO, et al; MRC Proteomics in ALS Study; FReJA Consortium. ALS phenotypes with mutations in CHMP2B (charged multivesicular body protein 2B). Neurology. 2006;67:1074-1077.

111. Cox LE, Ferraiuolo L, Goodall EF, et al. Mutations in CHMP2B in lower motor neuron predominant amyotrophic lateral sclerosis (ALS). PLoS One. 2010;5:e9872.

112. Chow CY, Landers JE, Bergren SK, et al. Deleterious variants of FIG4, a phosphoinositide phosphatase, in patients with ALS. Am J Hum Genet. 2009;84:85-88. 
113. Tsai CP, Soong BW, Lin KP, Tu PH, Lin JL, Lee YC. FUS, TARDBP, and SOD1 mutations in a Taiwanese cohort with familial ALS. Neurobiol Aging. 2011;32(3):553.e13-21.

114. Verdiani S, Origone P, Geroldi A, et al. The FIG4 gene does not play a major role in causing ALS in Italian patients. Amyotroph Lateral Scler Frontotemporal Degener. 2013;14:228-229.

115. Kon T, Mori F, Tanji K, et al. ALS-associated protein FIG4 is localized in Pick and Lewy bodies, and also neuronal nuclear inclusions, in polyglutamine and intranuclear inclusion body diseases. Neuropathology. 2014;34:19-26.

116. Deng HX, Chen W, Hong ST, et al. Mutations in UBQLN2 cause dominant X-linked juvenile and adult-onset ALS and ALS/dementia. Nature. 2011;477(7363):211-215.

117. Williams KL, Warraich ST, Yang S, et al. UBQLN2/ubiquilin 2 mutation and pathology in familial amyotrophic lateral sclerosis. Neurobiol Aging. 2012;33(10):2527.e3-10.

118. Gellera C, Tiloca C, Del Bo R, et al; SLAGEN Consortium. Ubiquilin 2 mutations in Italian patients with amyotrophic lateral sclerosis and frontotemporal dementia. J Neurol Neurosurg Psychiatry. 2013;84:183-187.

119. Chang L, Monteiro MJ. Defective proteasome delivery of polyubiquitinated proteins by ubiquilin-2 proteins containing ALS mutations. PLoS One. 2015;10:e 0130162.

120. Osaka M, Ito D, Yagi T, Nihei Y, Suzuki N. Evidence of a link between ubiquilin 2 and optineurin in amyotrophic lateral sclerosis. Hum Mol Genet. 2015;24:1617-1629.

121. Fecto F, Yan J, Vemula SP, et al. SQSTM1 mutations in familial and sporadic amyotrophic lateral sclerosis. Arch Neurol. 2011;68:1440-1446.

122. Teyssou E, Takeda T, Lebon V, et al. Mutations in SQSTM1 encoding p62 in amyotrophic lateral sclerosis: genetics and neuropathology. Acta Neuropathol. 2013;125:511-522.

123. Kwok CT, Morris A, de Belleroche JS. Sequestosome-1 (SQSTM1) sequence variants in ALS cases in the UK: prevalence and coexistence of SQSTM1 mutations in ALS kindred with PDB. Eur J Hum Genet. 2014;22:492-496.

124. Lattante S, de Calbiac H, Le Ber I, Brice A, Ciura S, Kabashi E. Sqstm1 knock-down causes a locomotor phenotype ameliorated by rapamycin in a zebrafish model of ALS/FTLD. Hum Mol Genet. 2015;24:1682-1690.

125. Luty AA, Kwok JB, Dobson-Stone C, et al. Sigma nonopioid intracellular receptor 1 mutations cause frontotemporal lobar degenerationmotor neuron disease. Ann Neurol. 2010;68:639-649.

126. Al-Saif A, Al-Mohanna F, Bohlega S. A mutation in sigma-1 receptor causes juvenile amyotrophic lateral sclerosis. Ann Neurol. 2011;70: 913-919.

127. Fukunaga K, Shinoda Y, Tagashira H. The role of SIGMAR1 gene mutation and mitochondrial dysfunction in amyotrophic lateral sclerosis. J Pharmacol Sci. 2015;127:36-41.

128. Maruyama H, Morino $\mathrm{H}$, Ito $\mathrm{H}$, et al. Mutations of optineurin in amyotrophic lateral sclerosis. Nature. 2010;465:223-226.

129. Kamada M, Izumi Y, Ayaki T, et al. Clinicopathologic features of autosomal recessive amyotrophic lateral sclerosis associated with optineurin mutation. Neuropathology. 2014;34:64-70.

130. Bansal M, Swarup G, Balasubramanian D. Functional analysis of optineurin and some of its disease-associated mutants. IUBMB Life. 2015;67:120-128.

131. van Blitterswijk M, van Vught PW, van Es MA, et al. Novel optineurin mutations in sporadic amyotrophic lateral sclerosis patients. Neurobiol Aging. 2012;33:1016.e1-1016.e7.

132. Beeldman E, van der Kooi AJ, de Visser M, van Maarle MC, van Ruissen F, Baas F. Dutch family with autosomal recessively inherited lower motor neuron predominant motor neuron disease due to optineurin mutations. Amyotroph Lateral Scler Frontotemporal Degener. 2015;16:410-411.

133. Goldstein O, Nayshool O, Nefussy B, et al. OPTN 691_692insAG is a founder mutation causing recessive ALS and increased risk in heterozygotes. Neurology. 2016;86(5):446-453.
134. Johnson JO, Mandrioli J, Benatar M, et al; ITALSGEN Consortium. Exome sequencing reveals VCP mutations as a cause of familial ALS. Neuron. 2010;68:857-864.

135. Meyer H, Weihl CC. The VCP/p97 system at a glance: connecting cellular function to disease pathogenesis. $J$ Cell Sci. 2014;127: 3877-3883.

136. Miller JW, Smith BN, Topp SD, Al-Chalabi A, Shaw CE, Vance C. Mutation analysis of VCP in British familial and sporadic amyotrophic lateral sclerosis patients. Neurobiol Aging. 2012;33(11):2721.e1-2.

137. Williams KL, Solski JA, Nicholson GA, Blair IP. Mutation analysis of VCP in familial and sporadic amyotrophic lateral sclerosis. Neurobiol Aging. 2012;33(4):837:e7-13.

138. Tiloca C, Ratti A, Pensato V, et al; SLAGEN Consortium. Mutational analysis of VCP gene in familial amyotrophic lateral sclerosis. Neurobiol Aging. 2012;33(3):630.e1-2.

139. Koppers M, van Blitterswijk MM, Vlam L, et al. VCP mutations in familial and sporadic amyotrophic lateral sclerosis. Neurobiol Aging. 2012;33(4):837.e7-13.

140. Abramzon Y, Johnson JO, Scholz SW, et al. Valosin-containing protein (VCP) mutations in sporadic amyotrophic lateral sclerosis. Neurobiol Aging. 2012;33(9):2231.e1-2231-e6.

141. Bartolome F, Wu HC, Burchell VS, et al. Pathogenic VCP mutations induce mitochondrial uncoupling and reduced ATP levels. Neuron. 2013;78:57-64.

142. Cirulli ET, Lasseigne BN, Petrovski S, et al. Exome sequencing in amyotrophic lateral sclerosis identifies risk genes and pathways. Science. 2015;347:1436-1441.

143. Freischmidt A, Wieland T, Richter B, et al. Haploinsufficiency of TBK1 causes familial ALS and fronto-temporal dementia. Nat Neurosci. 2015;18:631-636.

144. Gijselinck I, Van Mossevelde S, van der Zee J, et al; BELNEU Consortium. Loss of TBK1 is a frequent cause of frontotemporal dementia in a Belgian cohort. Neurology. 2015;85:2116-2125.

145. Le Ber I, De Septenville A, Millecamps S, et al; French Clinical and Genetic Research Network on FTLD/FTLD-ALS. TBK1 mutation frequencies in French frontotemporal dementia and amyotrophic lateral sclerosis cohorts. Neurobiol Aging. 2015;36:3116.e5-3116.e8.

146. Ahmad-Annuar A, Shah P, Hafezparast M, et al. No association with common Caucasian genotypes in exons 8,13 and 14 of the human cytoplasmic dynein heavy chain gene (DNCHC1) and familial motor neuron disorders. Amyotroph Lateral Scler Other Motor Neuron Disord. 2003;4:150-157.

147. Vilarino-Guell C, Wider C, Soto-Ortolaza AI, et al. Characterization of DCTN1 genetic variability in neurodegeneration. Neurology. 2009;72: 2024-2028.

148. Daoud H, Zhou S, Noreau A, et al. Exome sequencing reveals SPG11 mutations causing juvenile ALS. Neurobiol Aging.2012;33(4):839. e5-e9.

149. Orlacchio A, Babalini C, Borreca A, et al. SPATACSIN mutations cause autosomal recessive juvenile amyotrophic lateral sclerosis. Brain. 2010;133:591-598.

150. Perez-Branguli F, Mishra HK, Prots I, et al. Dysfunction of spatacsin leads to axonal pathology in SPG11-linked hereditary spastic paraplegia. Hum Mol Genet. 2014;23:4859-4874.

151. Wu CH, Fallini C, Ticozzi N, et al. Mutations in the profilin 1 gene cause familial amyotrophic lateral sclerosis. Nature. 2012;488:499-503.

152. Smith BN, Vance C, Scotter EL, et al. Novel mutations support a role for Profilin 1 in the pathogenesis of ALS. Neurobiol Aging. 2015;36(3):1602.e17-27.

153. Ingre $\mathrm{C}$, Landers JE, Rizik N, et al. A novel phosphorylation site mutation in profilin 1 revealed in a large screen of US, Nordic, and German amyotrophic lateral sclerosis/frontotemporal dementia cohorts. Neurobiol Aging. 2013;34:1708.e1701-1708.e1706.

154. Tiloca C, Ticozzi N, Pensato V, et al; SLAGEN Consortium. Screening of the PFN1 gene in sporadic amyotrophic lateral sclerosis and in frontotemporal dementia. Neurobiol Aging. 2013;34(5):1517.e9-10. 
155. van Blitterswijk M, Baker MC, Bieniek KF, et al. Profilin-1 mutations are rare in patients with amyotrophic lateral sclerosis and frontotemporal dementia. Amyotroph Lateral Scler Frontotemporal Degener. 2013;14:463-469.

156. Fratta P, Charnock J, Collins T, et al. Profilin1 E117G is a moderate risk factor for amyotrophic lateral sclerosis. J Neurol Neurosurg Psychiatry. 2014;85:506-508.

157. Figley MD, Bieri G, Kolaitis RM, Taylor JP, Gitler AD. Profilin 1 associates with stress granules and ALS-linked mutations alter stress granule dynamics. J Neurosci. 2014;34:8083-8097.

158. Boopathy S, Silvas TV, Tischbein M, et al. Structural basis for mutationinduced destabilization of profilin 1 in ALS. Proc Natl Acad Sci USA. 2015;112:7984-7989.

159. Smith BN, Ticozzi N, Fallini C, et al. Exome-wide rare variant analysis identifies TUBA4A mutations associated with familial ALS. Neuron. 2014;84:324-331.

160. Li J, He J, Tang L, et al. TUBA4A may not be a significant genetic factor in Chinese ALS patients. Amyotroph Lateral Scler Frontotemporal Degener. 2015;17(1-2):1-3.

161. Figlewicz DA, Krizus A, Martinoli MG, et al. Variants of the heavy neurofilament subunit are associated with the development of amyotrophic lateral sclerosis. Hum Mol Genet. 1994;3:1757-1761.

162. Al-Chalabi A, Andersen PM, Nilsson P, et al. Deletions of the heavy neurofilament subunit tail in amyotrophic lateral sclerosis. Hum Mol Genet. 1999;8:157-164.

163. Tomkins J, Usher P, Slade JY, et al. Novel insertion in the KSP region of the neurofilament heavy gene in amyotrophic lateral sclerosis (ALS). Neuroreport. 1998;9:3967-3970.

164. Gros-Louis F, Lariviere R, Gowing G, et al. A frameshift deletion in peripherin gene associated with amyotrophic lateral sclerosis. J Biol Chem. 2004;279:45951-45956.

165. Hand CK, Khoris J, Salachas F, et al. A novel locus for familial amyotrophic lateral sclerosis, on chromosome 18q. Am J Hum Genet. 2002;70:251-256.

166. Sapp PC, Hosler BA, McKenna-Yasek D, et al. Identification of two novel loci for dominantly inherited familial amyotrophic lateral sclerosis. Am J Hum Genet. 2003;73:397-403.

167. Takahashi Y, Fukuda Y, Yoshimura J, et al. ERBB4 mutations that disrupt the neuregulin-ErbB4 pathway cause amyotrophic lateral sclerosis type 19. Am J Hum Genet. 2013;93:900-905.
168. Gallart-Palau X, Tarabal O, Casanovas A, et al. Neuregulin-1 is concentrated in the postsynaptic subsurface cistern of C-bouton inputs to alpha-motoneurons and altered during motoneuron diseases. FASEBJ. 2014;28:3618-3632.

169. Bannwarth S, Ait-El-Mkadem S, Chaussenot A, et al. A mitochondrial origin for frontotemporal dementia and amyotrophic lateral sclerosis through CHCHD10 involvement. Brain. 2014;137:2329-2345.

170. Dols-Icardo O, Nebot I, Gorostidi A, et al; Dementia Genetics Spanish Consortium (DEGESCO). Analysis of the CHCHD10 gene in patients with frontotemporal dementia and amyotrophic lateral sclerosis from Spain. Brain. 2015;138:e400.

171. Johnson JO, Glynn SM, Gibbs JR, et al. Mutations in the CHCHD10 gene are a common cause of familial amyotrophic lateral sclerosis. Brain. 2014;137:e311

172. Marroquin N, Stranz S, Muller K, et al. Screening for CHCHD10 mutations in a large cohort of sporadic ALS patients: no evidence for pathogenicity of the p.P34S variant. Brain. Epub 2015 Sep 11.

173. Genin EC, Plutino M, Bannwarth S, et al. CHCHD10 mutations promote loss of mitochondrial cristae junctions with impaired mitochondrial genome maintenance and inhibition of apoptosis. EMBO Mol Med. 2015;8:58-72.

174. Cady J, Allred P, Bali T, et al. Amyotrophic lateral sclerosis onset is influenced by the burden of rare variants in known amyotrophic lateral sclerosis genes. Ann Neurol. 2015;77:100-113.

175. Steinberg KM, Yu B, Koboldt DC, Mardis ER, Pamphlett R. Exome sequencing of case-unaffected-parents trios reveals recessive and de novo genetic variants in sporadic ALS. Sci Rep. 2015;5:9124.

176. Chesi A, Staahl BT, Jovicic A, et al. Exome sequencing to identify de novo mutations in sporadic ALS trios. Nat Neurosci. 2013;16: 851-855.

177. Al-Chalabi A, Fang F, Hanby MF, et al. An estimate of amyotrophic lateral sclerosis heritability using twin data. J Neurol Neurosurg Psychiatry. 2010;81:1324-1326.

178. Millecamps S, Salachas F, Cazeneuve C, et al. SOD1, ANG, VAPB, TARDBP, and FUS mutations in familial amyotrophic lateral sclerosis: genotype-phenotype correlations. J Med Genet. 2010;47:554-560.

179. Kirby J, Goodall EF, Smith W, et al. Broad clinical phenotypes associated with TAR-DNA binding protein (TARDBP) mutations in amyotrophic lateral sclerosis. Neurogenetics. 2010;11:217-225.
Degenerative Neurological and Neuromuscular Disease

\section{Publish your work in this journal}

Degenerative Neurological and Neuromuscular Disease is an international, peer-reviewed, open access journal focusing on research into degenerative neurological and neuromuscular disease, identification of therapeutic targets and the optimal use of preventative and integrated treatment interventions to achieve improved outcomes, enhanced

\section{Dovepress}

survival and quality of life for the patient. The manuscript management system is completely online and includes a very quick and fair peer-review system. Visit http://www.dovepress.com/testimonials.php to read real quotes from published authors. 